\title{
Cinnamamide-Chalcone Derivatives as CDK2 Inhibitors: Synthesis, Pharmacological Evaluation, and Molecular Modelling Study
}

Akshada J. Joshi

KM Kundanani College of Pharmacy

Heena R. Bhojwani

KM Kundanani College of Pharmacy

Urmila Joshi ( $\square$ urmila.joshi1365@gmail.com )

KM Kundnani College of Pharmacy https://orcid.org/0000-0002-6166-1801

Khushboo V. Begwani

KM Kundanani College of Pharmacy

Ojas S. Wagal

KM Kundanani College of Pharmacy

Sadhana S. Sathaye

ICT: Institute of Chemical Technology

Divya M. Kanchan

Institute of Chemical Technology

\section{Research Article}

Keywords: Cinnamamide-chalcones, CDK2 Inhibition, Molecular Docking, Molecular Dynamics, Antiproliferative Activity

Posted Date: May 29th, 2021

DOl: https://doi.org/10.21203/rs.3.rs-528960/v1

License: (a) (1) This work is licensed under a Creative Commons Attribution 4.0 International License. Read Full License 


\section{Abstract}

A series of 13 novel cinnamamide-chalcone derivatives (2a-2m) were synthesized and evaluated for their antiproliferative activity against MCF-7, K562, U373MG, and HT-29 cell lines by SRB assay. Considering the activities on MCF-7 cell line, eight compounds were tested for the in-vitro CDK2 inhibition and four ( $2 \mathrm{~g}$, $2 \mathrm{~h}, 2 \mathrm{k}$ and $2 \mathrm{l})$ were found to possess good activity $\left(\mathrm{IC}_{50}<10 \mu \mathrm{M}\right)$. These four compounds were tested on EGFR kinase to assess the selectivity towards CDK2 and were found be nearly two times more selective. To corroborate the in-vitro enzyme assay data with binding, the compounds were docked into the CDK2 and EGFR using Glide software. The docking studies reveal that all eight compounds form hydrogen bonds with Lys33 ( $\beta-3$ region) and Leu83 (hinge region) in CDK2 and the docking scores correlate well with the $\mathrm{IC}_{50}$ values. The most active compounds on CDK2 when docked in EGFR had lower docking scores. Only one compound interacts with Lys721 ( $\beta-3$ region) and Met769 (hinge region). The stability of interactions with CDK2 was assessed for $\mathbf{2} \mathbf{k}$ and $\mathbf{2} \mathbf{l}$ by molecular dynamics simulation using Desmond software. In conclusion, three compounds possess excellent activity against MCF-7 cell line and good activity against CDK2.

\section{Introduction}

In mammalian cells, mitotic cell division is a sequence of complex events dominated by multiple protein kinase families [1]. Growth factor receptor kinases and Cyclin-dependent kinases (Cdks) regulate cell cycle engagement, DNA synthesis and onset of mitosis. Cyclin-dependent kinase-2 (CDK2) is an important cell cycle kinase involved in mitosis control. It is crucial in the transition from the $\mathrm{G} 1$ to the $\mathrm{S}$ phase, as well as progression through the $S$ phase $[2,3]$. Excessive Production of CDK2 or a lack of production of cyclin-dependent kinase inhibitor has been linked to cancer [4]. CDK2 inhibitors have been extensively investigated for their effects on the cell cycle and their possible utility in cancer treatment [5]. As a result, there has been a lot of interest in developing inhibitors that target CDK2 for cancer treatment.

Flavonoids are polyphenolic in nature and consist of a phenyl benzopyrone structure (C6-C3-C6). They are classified into flavones, flavanols, isoflavones, flavonols, flavanones, flavanonols, and chalcones based on the saturation frequency, C-ring substitution pattern, and central pyran ring opening [6]. Flavonoids are reported to block the cell cycle, induce apoptosis [7], disrupt mitotic spindle formation [8], or inhibit angiogenesis [9]. These properties make them promising anti-cancer agents. Naturally occurring flavonoids including genistein[6, 10], kampferol [6], apigenin[6, 11], and synthetic flavonoid such as flavopiridol [12] are (shown in Fig. 1) reported as inhibitors of CDK2 in different cancers. Additionally, some of the previous studies conducted in our laboratory on the evaluation of synthetic flavones as CDK2 inhibitors were encouraging [13]. The in-vitro enzyme assay suggested that the synthetic flavones possess good activity against CDK2 and molecular modeling studies indicated that Leu83 was critical in binding of these flavones.

Apart from these, some naturally occurring compounds like curcumin [14] as well as coumarins [15] are (shown in Fig. 1) also reported to bind to and inhibit CDK2. Chalcones such as isoliquiritigenin and 
licochalcone A (shown in Fig. 1), on the other hand, do not directly inhibit CDK2 but lead to G2/M arrest via induction of p21 and p27 as well as attenuation of CDK2 and CDK4/6 [16].

Cinnamic acid is a part of plant-derived scents and flavourings that has a long history of human use. It's an aromatic fatty acid with a phenyl ring substituted with an acrylic acid group, usually in the transgeometry. Cinnamic acid has an a, $\beta$-unsaturated carbonyl moiety, which acts as a Michael acceptor and is a form of active moiety used in the development of anticancer drugs. Cinnamic acid and its derivatives (shown in Fig. 1) display immunomodulatory effects, anti-inflammatory, anticancer, and antioxidant properties $[16,17]$. They've been one of the most important sources of potential anticancer compounds.

All of these reports highlight the importance of both the $a, \beta$-unsaturated carbonyl moieties as well as cinnamoyl moiety for CDK2 inhibition. Given these facts, we decided to design and synthesize cinnamoyl chalcone derivatives (2a-2m), as shown in Fig. 2 and evaluate them for antiproliferative activity against cancer cell lines. The compounds with promising antiproliferative activities were then evaluated for their ability to bind to and inhibit the kinase activities CDK2. This was done using the enzyme inhibition assays as well as in-silico methods such as docking and molecular dynamics simulation. Additionally, four compounds with good activities against CDK2 were tested against EGFR kinase in an attempt to understand the selectivity.

\section{Results And Discussion}

\section{Synthesis}

The synthetic route adopted for the synthesis of the new cinnamamide chalcone derivatives is depicted in Scheme 1. The intermediate N-(3-acetylphenyl) cinnamamide (3) was prepared by refluxing 3'aminoacetophenone (1) and cinnamoyl chloride (2) for 4 hours in acetone with potassium carbonate as hydrogen chloride acceptor. Further, N-(3-acetylphenyl) cinnamamide (3) weas stirred with substituted benzaldehydes (4) in presence of Lithium Hydroxide Monohydrate in ethanol and converted to the cinnamamide (2a-2m) chalcones. All the synthesized compounds were characterized by Infrared (IR) Spectroscopy, ${ }^{1} \mathrm{H}-\mathrm{NMR},{ }^{13} \mathrm{C}-\mathrm{NMR}$, and melting point analysis.

All the synthesized compounds were characterized by Infrared (IR) Spectroscopy, 1H NMR, 13C NMR, and melting point analysis. The synthesis of new cinnamamide chalcones was indicated in the FTIR spectra by the presence of a singlet around 3300 (-NH- group) and 1650-1660 (-C=0 group) $\mathrm{cm}^{-1}$ that were assigned to cinnamamide group. The spectrum also showed another singlet at around $1612 \mathrm{~cm}^{-1}$ corresponding to ketone. The $\mathrm{NH}$ amide proton appeared between $\delta 10.20-10.50 \mathrm{ppm}$ in the ${ }^{1} \mathrm{H}-\mathrm{NMR}$ spectra and carbonyl amide carbon appeared around $164 \mathrm{ppm}$ in the ${ }^{13} \mathrm{C}-\mathrm{NMR}$ spectra. The appearance of doublets at about $\delta$ 7.4-7.7ppm and 7.6-7.8 ppm with $\mathrm{J}$ values around $15-16 \mathrm{~Hz}$ corresponding to transcoupling confirmed presence of $a, \beta$-unsaturated ketone in chalcones. This is also supported by the appearance of a peak around $8189.00 \mathrm{ppm}$ in ${ }^{13} \mathrm{C}-\mathrm{NMR}$ indicating the carbonyl carbon of a, $\beta-$ unsaturated ketone. The peak around $8164.00 \mathrm{ppm}$ in ${ }^{13} \mathrm{C}-\mathrm{NMR}$ indicates the presence of the carbonyl 
carbon belonging to the cinnamamide group. All the spectral details comply with usually reported values [18]. The spectral data is provided in the Supplementary Material.

\section{Biological Assays}

\section{Antiproliferative activity by SRB assay}

All the synthesized compounds were tested on MCF-7 and K562 cell line considering the involvement of CDK2 in breast cancer $[3,4,19]$ and leukaemia $[3,4,20]$ by SRB assay. Adriamycin was used as a positive control in this assay $[21,22]$. The reason for including Adriamycin as a positive control was to ensure that the cells respond to the standard antiproliferative treatment. Three compounds $2 \mathrm{~g}$, $2 \mathrm{i}$, and $2 \mathrm{k}$ possess excellent activity against MCF-7 cell line. Compounds $\mathbf{2 e}, \mathbf{2} \mathbf{h}, \mathbf{2} \mathbf{j}$, and $\mathbf{2 l}$ were found to have moderate activity while remaining compounds were weakly active. Most compounds were weakly active or inactive on $\mathrm{K} 562$ cell line. Compounds with $\mathrm{Gl}_{50}$ values less than $50 \mu \mathrm{M}, v i z . \mathbf{2 e}, \mathbf{2 f}, \mathbf{2} \mathbf{g}, \mathbf{2} \mathbf{h}, \mathbf{2} \mathbf{i}, \mathbf{2} \mathbf{j}, \mathbf{2 k}$, and $\mathbf{2 l}$ on MCF-7 cell line were tested on two more cell lines viz. HT29 (colon cancer) and U373MG (glioblastoma) $[3,4]$. Compound $\mathbf{2} \mathbf{i}, \mathbf{2} \mathbf{k}$, and $\mathbf{2} \mathbf{l}$ were moderately active on $\mathrm{HT} 29$ cell line while compound $\mathbf{2} \mathbf{j}$ was weakly active. Compounds $\mathbf{2 e}, \mathbf{2 f}, \mathbf{2} \mathbf{g}$, and $\mathbf{2 h}$ were inactive. Compounds $\mathbf{2 e}, \mathbf{2} \mathbf{g}$, $\mathbf{2} \mathbf{i}$, and $\mathbf{2 l}$ were moderately active on U373MG while the other compounds were inactive. The \% Control Growth at different concentrations of the compounds for these cell lines are shown in the Supplementary Material Fig. S1-S4.

\section{CDK2 and EGFR Kinase Inhibition by ADP Glo ${ }^{\mathrm{TM}}$ Assay}

Considering the activities obtained in the SRB assay, compounds ( $2 \mathbf{e}, \mathbf{2 f}, \mathbf{2 g}, \mathbf{2 h}, \mathbf{2 i}, \mathbf{2 j}, \mathbf{2 k}$, and $2 \mathbf{l})$ with $\mathrm{GI}_{50}$ values less than $50 \mu \mathrm{M}$ on MCF7 cell line were further tested for the CDK2 inhibition by in-vitro assay. Staurosporine was used as a positive control in this assay [23, 24]. Enzyme titration curve for CDK2 is given in Supplementary Material Fig. S5. Compound $2 \mathrm{~g}, \mathbf{2 h}, \mathbf{2 k}$ and $2 \mathrm{l}$ were found to exhibit good activity against CDK2 while $\mathbf{2} \mathbf{e}, \mathbf{2} \mathbf{f}, \mathbf{2} \mathbf{i}$, and $\mathbf{2} \mathbf{j}$ were moderately active. Only with an exception of compound $\mathbf{2} \mathbf{l}$, there seemed to be a good correlation between the CDK2 inhibition and antiproliferative effect on MCF7 cell line. However, such a correlation could not be established in case of the other cell lines.

Once we were able to demonstrate inhibition of CDK2, we decided to study the selectivity of these compounds in inhibiting the CDK2. Kinase inhibitors are reported to show a variable cross reactivity with other kinases. This is because of a common active site architecture of multiple kinases increasing the cross-inhibition potential. Literature reports multiple scaffolds which act as both CDK2 and EGFR inhibitors [25-29]. In order to explore the selectivity [30], we decided to test the most active CDK2 inhibitors, i.e. compounds with $\mathrm{IC}_{50}<10 \mu \mathrm{M}$ in the CDK2 enzyme inhibition assay, for their ability to inhibit another kinase, that is EGFR. Enzyme titration curve for EGFR is given in Supplementary Material Fig. S6. The results of EGFR inhibition assay indicate that the compounds under study gave a selectivity score of 1.84-2.56. Straurosporine also gave a selectivity ratio of about 2.8 .

Table $1 \mathrm{GI}_{50}$ values from the SRB assay and $\mathrm{IC}_{50}$ values from in-vitro enzyme assay for the synthesized compounds 


\begin{tabular}{|c|c|c|c|c|c|c|c|c|}
\hline Compounds & $\mathrm{R}$ & $\begin{array}{l}\text { MCF- } \\
7 \\
(\mu \mathrm{M})\end{array}$ & $\begin{array}{l}\mathrm{K} 562 \\
(\mu \mathrm{M})\end{array}$ & $\begin{array}{l}\text { U373MG } \\
(\mu \mathrm{M})\end{array}$ & $\begin{array}{l}\mathrm{HT}- \\
29 \\
(\mu \mathrm{M})\end{array}$ & $\begin{array}{l}\mathrm{IC}_{50} \\
\mathrm{CDK} 2 \\
(\mu \mathrm{M})\end{array}$ & $\begin{array}{l}\mathrm{IC}_{50} \\
\text { EGFR } \\
(\mu \mathrm{M})\end{array}$ & $\begin{array}{l}\text { Selectivity for } \\
\text { CDK2 }\end{array}$ \\
\hline $2 a$ & $3-\mathrm{OCH}_{3}$ & 72 & 72.2 & - & - & - & - & \\
\hline $2 b$ & $4-\mathrm{OCH}_{3}$ & 60.8 & 56.3 & - & - & - & - & \\
\hline $2 c$ & $\begin{array}{l}3,4- \\
\mathrm{OCH}_{3}\end{array}$ & 71.4 & $>100$ & - & - & - & - & \\
\hline $2 d$ & $\begin{array}{l}2,5- \\
\mathrm{OCH}_{3}\end{array}$ & 77.4 & $>100$ & - & - & - & - & \\
\hline $2 e$ & $2-\mathrm{F}$ & 26.2 & 48.3 & 28.8 & $>100$ & 13.50 & - & \\
\hline $2 f$ & $3-F$ & 23.5 & $>100$ & $>100$ & $>100$ & 10.59 & - & \\
\hline $2 g$ & $4-\mathrm{F}$ & $<0.1$ & 52.4 & 26.9 & $>100$ & 5.64 & 13.12 & 2.32 \\
\hline $2 \mathrm{~h}$ & $2-\mathrm{Cl}$ & 30 & $>100$ & $>100$ & $>100$ & 22.19 & - & \\
\hline $2 i$ & $3-\mathrm{Cl}$ & $<0.1$ & 46.5 & 24.1 & 27.2 & 5.95 & 15.29 & 2.56 \\
\hline $2 j$ & $4-\mathrm{Cl}$ & 23.6 & 93.3 & $>100$ & 67.5 & 18.80 & - & \\
\hline $2 k$ & $3,4-\mathrm{Cl}$ & $<0.1$ & 50.3 & $>100$ & 16.9 & 4.07 & 7.94 & 1.95 \\
\hline 21 & $3-\mathrm{NO}_{2}$ & 20.9 & 31.3 & 15.9 & 19.5 & 5.00 & 9.24 & 1.84 \\
\hline $2 m$ & $4-\mathrm{NO}_{2}$ & 59 & $>100$ & - & - & - & - & \\
\hline Adriamycin & - & $<0.1$ & $<0.1$ & $<0.1$ & $<0.1$ & - & - & \\
\hline Staurosporine & - & - & - & - & - & 0.74 & 2.11 & 2.85 \\
\hline
\end{tabular}

Note: '-' indicates Not Tested

\section{In-silico Computational Studies}

\section{Molecular docking}

Our previous work on the selecting of the most suitable crystal structure for docking into CDK2 receptor had indicated that $2 \mathrm{WXV}$ is the most suitable crystal structure for docking of chemically diverse ligands. This prompted us to use this crystal structure for docking of CDK2 inhibitors [31]. The docking protocol was validated by calculating RMSD values between the docked conformation of the inhibitor and native conformation. Thus, an RMSD value of $0.7685 \AA$ for $2 W X V$ (CDK2) between the docked conformation of the inhibitor and native conformation depicted the accuracy of the docking program (shown in Supplementary Material Fig. S7). In order to assess the accuracy, the interactions produced on re-docking 
were checked with that of the interactions observed in native conformation for WXV (shown in Supplementary Material Fig. S8).

Eight compounds were subjected to the docking studies for understanding their binding to CDK2 kinase. The docking score and the 3D ligand interaction pose are given in the Supplementary Material Table S1. The 2D ligand interaction diagram is shown in Fig. 3. Compound $\mathbf{2 l}$ docked in the CDK2 structure with the highest dock score $(-8.594 \mathrm{kcal} / \mathrm{mol})$. a, $\beta$-unsaturated carbonyl group acted as a hydrogen bond acceptor from the backbone $\mathrm{NH}$ of Leu83. The carbonyl group from the cinnamamide also acted as a hydrogen bond acceptor for the side chain $\mathrm{NH}$ from Lys 33. Additional, hydrogen bonding interactions were seen between side-chain NH of Gln131 and 3-nitro group. Salt-bridge was seen with Asp86.

Compound $\mathbf{2 k}$ was identified as the most active compound in the in-vitro enzyme assay however; its docking score was slighltly lower than compound $\mathbf{2 l}$. Compound $\mathbf{2} \mathbf{k}$ binds into CDK2 (PDB id 2WXV) with dock score $-8.025 \mathrm{kcal} / \mathrm{mol}$. a, $\beta$-unsaturated carbonyl group acted as a hydrogen bond acceptor from the backbone $\mathrm{NH}$ of Leu83. The carbonyl group from the cinnamamide also acted as a hydrogen bond acceptor for the side chain NH from Lys 33. Additionally, pi-pi interactions were made with the Phe80.

All compounds form hydrogen bonding interactions with Lys33 and Leu83 except compound $2 \mathbf{j}$ wherein interactions between carbonyl group from cinnamamide and Leu83 were only formed. The pi-pi stacking with Phe80 seems to be an important but not a compulsory interaction for the compounds to be active as it was not observed in case of all compounds. The interactions observed in this study are consistent with some of the other reported studies [13, 32, 33-37].

Further, all compounds except $\mathbf{2} \mathbf{h}, \mathbf{2} \mathbf{j}$, and $\mathbf{2 l}$ adopt a similar type of inverted "U-shaped"orientation in the CDK2 active site. Compound $\mathbf{2 e}$ adopts an inverted "U-shaped" orientation however; the 2-chlorophenyl ring orients slightly away from the Asp145 (DFG-motif) as seen in the other compounds. Compound 2j adopts a "C-shaped" orientation in the active site which might be attributed to the absence of interactions with Lys33. A slight difference is observed in the orientation of the compound $\mathbf{2 l}$. Compound $\mathbf{2}$ has an inverted "U-shaped" orientation but the position of the 3-nitrophenyl ring is slightly away from Leu83 than observed in the other compounds. These differences in the orientation and interactions might be responsible for the differences in the activity observed in the in-vitro assay and are provided in the Table S1. Similar orientations have been previously reported for the protein kinase inhibitors $[38,39]$.

The compounds tested on EGFR in the in-vitro assay were also studied in the molecular docking studies. The docking protocol for EGFR was valiadated by redocking the co-crystallized ligand AQ4 and the RMSD was $0.2607 \AA$ (shown in Supplementary Material Fig. S9). The interactions for AQ4 are provided in the Supplementary Material Fig. S10. The results of docking studies indicate that compounds dock with scores lower than CDK2 kinase and are provided in Supplementary Material Table S2. The interaction analysis for the compounds reveals that compounds $\mathbf{2 g}, \mathbf{2 i}, \mathbf{2 k}$, and $\mathbf{2 l}$ interact with Met769 from the hinge region. $2 \mathrm{~g}$ interacts additionally via hydrogen bonding with Lys721 from $\beta-3$ region. In this case, only compound $2 \mathrm{~g}$ adopts a roughly inverted "U-shaped" orientation. Compound $2 \mathrm{k}$ adopts a "Cshaped"orientation while $2 \mathrm{l}$ adopts an extended orientation. Compound $2 \mathrm{i}$ has an unspecified shape. 
These different orientations might be due to the lack of interaction with Lys721. The mode of binding and the interactions are different in case of EGFR than CDK2. These results corroborate well with in-vitro assay results.

\section{Molecular Dynamics Simulation}

The docked complexes for $\mathbf{2} \mathbf{l}$ and $\mathbf{2} \mathbf{k}$ were validated for the stability of complex formation, implementing a MD simulation using Desmond software. The production run was carried out for 20ns. The RMSD plots for the protein (shown in Supplementary Material Fig. S11) showed no significant increase in RMSD for the protein viz. CDK2 until the completion of production run in case of both compounds. The ligand RMSD values were calculated with respect to the docked pose (Lig fit on Prot shown in Fig. S11) throughout the simulation and found to be stable during the most period of the production run. There were some changes for brief period indicating changes in the interaction between the protein and ligand. However, these values were lower than the RMSD values calculated for the protein indicating that the ligands did not move away from the active site. Similarly, the RMSF plots (shown in Supplementary Material Fig. S11) do not show any fluctuations for the protein where these compounds interact with residues in regions including alpha-helices or beta-sheets. The only exception is the loop region where usually the fluctuations are common due to the flexibility. These findings suggest a stable complex formation for compound $2 \mathrm{l}$ and $2 \mathrm{k}$ with CDK2.

As the CDK2-2l interactions in the docked pose were slightly different than the other compounds, the molecular dynamics simulation was performed for this complex primarily. Hydrogen bonding interactions were observed for $64 \%$ and $86 \%$ of simulation time with Leu83 and Lys33; respectively. GIn85 and GIn 131 also interact via hydrogen bonding but these are shortlived interactions. Pi-pi stacking interactions were seen with Tyr 15 for $58 \%$ time of the total duration. Interactions with Phe80 were also observed but were for less than $20 \%$ of the time. Other hydrophobic interactions were seen with lle10, Tyr15, and Leu134 for more than $40 \%$ of the time. Some hydrophobic and pi-cation interactions were seen with other amino acid residues for less than $30 \%$ of the time. These interactions are shown in Fig. 5. The molecular dynamics simulation studies for compound $2 \mathrm{I}$ indicate that the hydrogen bonding between the ligand and Leu83 as well Lys33 are important while GIn131 are not contributing much to the binding. Likewise, the ionic interactions with Asp86 also doesn't seem to be contributing towards the binding in any manner.

The CDK2-2k interactions were also monitored throughout the simulation. The histogram plot shows that hydrogen bonding interactions were observed for $81 \%$ and $58 \%$ of simulation time with Leu 83 and Lys33; respectively. Similar interaction was seen with Asn 132 only for less than $10 \%$ of the total simulation time. For nearly and more than $40 \%$ of the simulation time, hydrophobic interactions were observed with lle 10 , Tyr15, Ala31, Phe82, and Leu134. Pi-pi stacking with Phe80 similar to the docked pose were observed but for a less significant period. Pi-pi stacking interactions were observed with Tyr 15 for $41 \%$ of the time. This interaction was not seen in the docked pose and seems to be contributing to the stability. Watermediated hydrogen bonding was observed with $\mathrm{G} \ln 131$ for $34 \%$ of the times. 
Overall, the molecular dynamics simulation studies indicates that the activity of these compounds towards CDK2 can be attributed to the interactions with Lys33 and Leu83 majorly. Interactions with Tyr15 might also be responsible for the additional stability as seen in compound 21 . In some cases, watermediated interactions might also be responsible for the stability as seen in case of compound $2 k$.

\section{Conclusion}

A series of Cinnamamide-chalcone derivatives (2a-2m) were designed as potential antiproliferative agents and CDK2 inhibitors. They were synthesised and characterized using different spectroscopic techniques. Their cytotoxic activities against four different cancer cell lines MCF-7, K-562, HT-29, and U373MG. The synthesised compounds showed strong to moderate cytotoxic activities against MCF-7 cell line. The most active compounds against MCF-7 were $\mathbf{2} \mathbf{g}, \mathbf{2} \mathbf{i}$, and $\mathbf{2} \mathbf{k}$ while on the other cell lines either the compounds have moderate, weak, or no activity. Moreover, CDK2 inhibitory activities were determined for the active and moderately active compounds. Compounds $\mathbf{2 g}, \mathbf{2 h}, \mathbf{2 k}$ and $2 \mathrm{l}$ showed good inhibitory activity against CDK2 and these were also tested on EGFR. All four compounds were more selective for CDK2. Docking studies of CDK2 indicate the hydrogen bonding interactions observed with Lys 33 and Leu83 are critical for the binding. These were stable through simulation period for the most active compound $\mathbf{2} \mathbf{k}$ and $\mathbf{2}$ l. In case of EGFR, the docking studies show that the compound forms one hydrogen bonding interaction with Met769 in three compounds while one compound interacts with Cys773. These interactions might be a reason for the weaker activity on EGFR kinase and greater selectivity towards

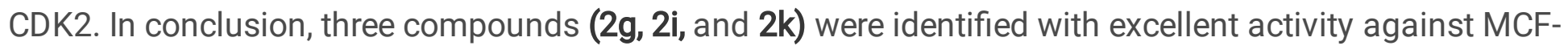
7 cell line and good activity againd CDK2 in the present study. One compound (2l) possesses good activity against CDK2 and MCF-7 cell line as well as better activity against the remaining cell lines. These cinnamamide-substituted chalcone derivatives will be useful as lead molecules for the further structural modifications and development of newer inhibitors of CDK2.

\section{Materials And Methods}

\section{Materials}

All chemicals and reagents used for synthesis were purchased from Loba Chemie, Sigma Aldrich, and SD Fine Chemicals Pvt. Ltd, India. All the reactions were monitored using thin layer chromatography (TLC) on pre-coated TLC plates (Silica gel GF254) using various solvent systems. Melting points were taken in open capillary tubes using ANALAB $\mu$ ThermoCal10 melting point apparatus and were uncorrected. The structures of the synthesized compounds were confirmed by Infrared (IR) spectroscopy and Nuclear Magnetic Resonance (NMR) spectroscopy. IR spectroscopy was carried out using KBr pellet method on the Perkin Elmer Spectrum 10.4.2 and Shimadzu IRAffinity-1. NMR spectra were recorded on a Bruker Avance 500 spectrophotometer operating at $500 \mathrm{MHz}\left({ }^{1} \mathrm{H}\right.$ and ${ }^{13} \mathrm{C}$ NMR). Samples were dissolved $(20 \mathrm{mg} / \mathrm{ml})$ in hexadeuterated dimethylsulfoxide (DMSO-d6), and spectra were recorded at $323 \mathrm{~K}$. Column chromatography was carried out using silica gel (230/400 mesh). 


\section{Methods}

\section{Synthesis of cinnamamide chalcones $(2 \mathrm{a}-2 \mathrm{~m})$}

A mixture of 3-aminoacetophenone ( $0.01 \mathrm{moles})$ and cinnamoyl chloride $(0.01 \mathrm{moles})$ was refluxed under acetone $(20 \mathrm{ml})$ and potassium carbonate $(0.001 \mathrm{moles})$ for $4 \mathrm{~h}$. The completion of the reaction was monitored by TLC. The mixture was then decanted to remove potassium carbonate and then allowed to stand overnight to obtain a white solid of $\mathrm{N}$-(3-acetylphenyl) cinnamamide [40, 41]. It was then filtered under vacuum to obtain the dry intermediate of $\mathrm{N}$-(3-acetylphenyl) cinnamamide.

$\mathrm{N}$-(3-acetylphenyl) cinnamamide in anhydrous ethanol $(20 \mathrm{ml})$ was treated with lithium hydroxide monohydrate $(0.003$ moles $)$ under magnetically stirred condition for $15 \mathrm{~min}$ at room temperature. The substituted benzaldehyde $(0.01 \mathrm{moles})$ was added to the stirring mixture [42]. Stirring was continued for 6 h. The reaction was confirmed for completion by TLC. The reaction mixture was acidified with $1 \%$ aqueous $\mathrm{HCl}$ to give crude product. The resulting product was filtered and recrystallized from ethanol.

\section{1-(3'-cinnamaamidophenyl)-3-(3"-methoxyphenyl)-prop-2-en-1-one (2a)}

White (pale) colored solid, yield (69.20\%). mp:169² $\mathrm{F}$ FTIR (KBr, cm-1): 3344.57 (N-H stretch of anilide), 1662.64 ( $C=0$ stretch of anilide), 1612.49 ( $C=0$ stretch of $a, \beta$ unsaturated ketone), 1514.12 (aromatic $\mathrm{C}=\mathrm{C}$ stretch), 1251.8 (asymmetric $\mathrm{C}-\mathrm{O}-\mathrm{C}$ stretch, $\mathrm{OCH}_{3}$ ), 1033.85 (symmetric C-O-C stretch, $\mathrm{OCH}_{3}$ ); ${ }^{1} \mathrm{H}$ NMR (DMSO-d ${ }_{6}, \delta$ ppm): 10.299 (s, 1H, NH), 8.188 (s, 1H, H-2'), 7.904 (d, 1H, H-4'), 7.788 (d, 1H, H-6'), 7.734 (d, $1 \mathrm{H}, \mathrm{H}-3), 7.598$ (d, 1H, H-2), 7.503 (m, 3H, H-2"',6"',6), 7.427 (t, 1H, H-5'), 7.323 (m, 5H, H-3"', 4"', 5"',6", 2"), $7.252\left(\mathrm{t}, 1 \mathrm{H}, \mathrm{H}-5\right.$ "), 6.905 (d, 1H, H-4"), $6.716(\mathrm{~d}, 1 \mathrm{H}, \mathrm{H}-5), 3.686\left(\mathrm{~s}, 3 \mathrm{H}, \mathrm{OCH}_{3}\right) ;{ }^{13} \mathrm{C}$ NMR $\delta$ ppm $189.580(\mathrm{C}-$ 1), 164.199 (C-4), 160.064 (C-3"), 144.526 (C-3), 140.978 (C-6), 140.145 (C-1'), 138.549(C-3'), 136.429 (C1"'), 135.014 (C-1"), 130.348 (C-5'), 130.262 (C-5"), 129.712 (C-4"', $\left.4^{\prime}\right), 129.416$ (C-3"', 5"'), 128.161 (C-2"', 6"'), 124.163 (C-6'), 122.863 (C-2), 122.377 (C-6"), 121.881 (C-2'), 119.197 (C-5), 117.067 (C-4”), 113.908 (C-2"), $55.697\left(-\mathrm{OCH}_{3}\right)$.

\section{1-(3'-cinnamaamidophenyl)-3-(4"-methoxyphenyl)-prop-2-en-1-one (2b)}

Yellow colored solid, yield (76.12\%). mp:176 ${ }^{\circ} \mathrm{C}$; FTIR ( $\left.\mathrm{KBr}, \mathrm{cm}-1\right)$ : 3322.99 (N-H stretch of anilide), 1656.85 ( $C=0$ stretch of anilide), 1612.49 ( $C=0$ stretch of $a, \beta$ unsaturated ketone), 1514.12 (aromatic $C=C$ stretch), 1251.8 (asymmetric C-O-C stretch, $\mathrm{OCH}_{3}$ ), 1033.85 (symmetric $\mathrm{C}-\mathrm{O}-\mathrm{C}$ stretch, $\mathrm{OCH}_{3}$ ); ${ }^{1} \mathrm{H}$ NMR

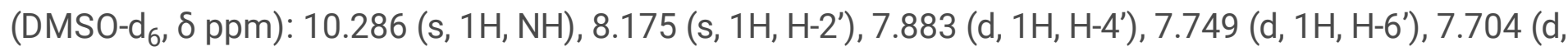
2H, H-2"',6"'), 7.582 (d, 1H, H-3), 7.575 (d, 1H, H-2), 7.501 (m, 3H, H-6,2",6"), 7.410 (t, 1H, H-5'), 7.329 (m, 3H, $\left.\mathrm{H}-3^{\prime \prime \prime}, 4^{\prime \prime \prime}, 5^{\prime \prime \prime}\right), 6.895\left(\mathrm{~d}, 1 \mathrm{H}, \mathrm{H}-3^{\prime \prime}, 5^{\prime \prime}\right), 6.713(\mathrm{~d}, 1 \mathrm{H}, \mathrm{H}-5), 3.682\left(\mathrm{~s}, 3 \mathrm{H}, \mathrm{OCH}_{3}\right) ;{ }^{13} \mathrm{C} \mathrm{NMR} \delta \mathrm{ppm} 189.362$ (C-1), 164.187 (C-4), 161.832 (C-4"), 144.558 (C-3), 140.956 (C-6), 140.095 (C-1'), $138.864\left(\mathrm{C}-3^{\prime}\right), 135.019$ (C-1"'), 131.121 (C-2",6"), 130.268 (C-5'), 129.669 (C-4"'), 129.424 (C-3"',5"'), 128.162 (C-2"',6"'), 127.642 (C-4',1"), 123.970 (C-6'), 122.397 (C-2), 120.009 (C-2'), 119.130 (C-5), $114.859\left(\mathrm{C}-\mathrm{C}^{\prime \prime}, 5^{\prime \prime}\right), 55.778\left(\mathrm{OCH}_{3}\right)$. 
Yellow (bright) colored solid, yield (58.52\%). mp: $180^{\circ} \mathrm{C}$; FTIR (KBr, cm-1): 3319.49 (N-H stretch of anilide), 1656.85 ( $\mathrm{C}=\mathrm{O}$ stretch of anilide), 1612.49 ( $\mathrm{C}=\mathrm{O}$ stretch of $\mathrm{a}, \beta$ unsaturated ketone), 1514.12 (aromatic $\mathrm{C}=\mathrm{C}$ stretch), 1251.8 (asymmetric $\mathrm{C}-\mathrm{O}-\mathrm{C}$ stretch, $\mathrm{OCH}_{3}$ ), 1033.85 (symmetric C-O-C stretch, $\mathrm{OCH}_{3}$ ); ${ }^{1} \mathrm{H}$ NMR (DMSO-d 6 , $\delta$ ppm): 10.290 (s, 1H, NH), 8.149 (s, 1H, H-2'), 7.901 (d, 1H, H-4'), 7.775 (d, 1H, H-6'), 7.622 (d, $1 \mathrm{H}, \mathrm{H}-3), 7.581$ (d, 1H, H-2), 7.501 ( $\left.m, 3 \mathrm{H}, \mathrm{H}-2^{\prime \prime \prime}, 6^{\prime \prime}, 6\right), 7.420$ (m, 2H, H-5',2"), 7.329 (m, 4H, H-3"', 4"', 5"', 6"), 6.899(d, 1H, H-5"), 6.718 (d, 1H, H-5), 3.714 and $3.677\left(\mathrm{~s}, 6 \mathrm{H}, \mathrm{OCH}_{3}\right) ;{ }^{13} \mathrm{C}$ NMR $\delta$ ppm 189.458 (C-1), 164.183 (C-4), 151.752 (C-3"), 149.437 (C-4"), 145.109 (C-3), 140.946 (C-6), 140.094 (C-1'), 138.933 (C-3'), 135.020 (C-1"'), 130.257 (C-5'), 129.617 (C-4"'), 129.418 (C-3"', $\left.5^{\prime \prime \prime}\right), 128.158$ (C-2"',6"'), 127.858 (C-4'), 124.196 (C-1"), 124.070 (C-6'), 123.930 (C-6"), 122.407 (C-2), 120.179 (C-2'), 119.104 (C-5), 112.015 (C-5"), $111.312\left(\mathrm{C}-2^{\prime \prime}\right), 56.143\left(3^{\prime \prime}-\mathrm{OCH}_{3}\right), 55.998\left(4^{\prime \prime}-\mathrm{OCH}_{3}\right)$.

\section{1-(3'-cinnamaamidophenyl)-3-(2",5"-dimethoxyphenyl)-prop-2-en-1-one (2d)}

Yellow colored solid, yield (71.19\%). mp:175² ; FTIR (KBr, cm-1): 3319.42 (N-H stretch of anilide), 1662.44 ( $C=0$ stretch of anilide), 1612.49 ( $C=0$ stretch of $a, \beta$ unsaturated ketone), 1514.12 (aromatic $C=C$ stretch), 1251.8 (asymmetric C-O-C stretch, $\mathrm{OCH}_{3}$ ), 1031.92 (symmetric $\mathrm{C}-\mathrm{O}-\mathrm{C}$ stretch, $\mathrm{OCH}_{3}$ ); ${ }^{1} \mathrm{H}$ NMR (DMSO-d ${ }_{6}, \delta$ ppm): 10.473 (s, 1H, NH), 8.345 (s, 1H, H-2'), 8.053 (m, 2H, H-4',3), 7.931 (m, 2H, H-6',2), 7.666 (m, 3H, H-2"',6"',6), $7.583\left(\mathrm{~m}, 2 \mathrm{H}, \mathrm{H}-5^{\prime}, 3^{\prime \prime}\right), 7.474\left(\mathrm{~m}, 4 \mathrm{H}, \mathrm{H}-3^{\prime \prime}, 4^{\prime \prime}, 5^{\prime \prime}, 4^{\prime \prime}\right), 7.071$ (s, 1H, H-6"), 6.879 (d, 1H, H-6), 3.870 and 3.811 (s, 6H, OCH $)_{3}$; ${ }^{13} \mathrm{C}$ NMR $\delta$ ppm 189.721 (C-1), 164.300 (C-4), 153.719 (C-5"), 153.290 (C2"), 141.091 (C-6), 140.218 (C-3), 139.076 (C-1'), 139.038 (C-3'), 137.087 (C-1"'), 135.089 (C-5'), 130.400 (C$\left.4^{\prime \prime \prime}\right), 130.330$ (C-4'), 129.526 (C-3"', $\left.5^{\prime \prime \prime}\right), 128.290\left(\mathrm{C}-2^{\prime \prime \prime}, 6^{\prime \prime}\right), 124.144$ (C-6',2), 122.740 (C-2'), 122.467 (C-5), $119.212(\mathrm{C}-1 "), 118.589(\mathrm{C}-3 "), 113.412(\mathrm{C}-4 ", 6 "), 56.629\left(2^{\prime \prime}-\mathrm{OCH}_{3}\right), 56.185\left(5^{\prime \prime}-\mathrm{OCH}_{3}\right)$.

\section{1-(3'-cinnamaamidophenyl)-3-(2"-fluorophenyl)-prop-2-en-1-one (2e)}

White (pale) colored solid, yield (89.92\%). mp:158 ${ }^{\circ} \mathrm{C}$; FTIR (KBr, cm-1): 3341.41 (N-H stretch of anilide), 1659.96 ( $\mathrm{C}=\mathrm{O}$ stretch of anilide), 1599.77 ( $\mathrm{C}=\mathrm{O}$ stretch of $\mathrm{a}, \beta$ unsaturated ketone), 1516.31 (aromatic $\mathrm{C}=\mathrm{C}$ stretch), 752.0 (C-F stretch) ; ${ }^{1} \mathrm{H}$ NMR (DMSO- ${ }_{6}, \delta \mathrm{ppm}$ ): 10.491 (s, 1H, NH), $8.383\left(\mathrm{~s}, 1 \mathrm{H}, \mathrm{H}-2^{\prime}\right), 8.115$ (t, 1H, H-5'), 8.059 (d, 1H, H-4'), 7.950 (m, 2H, H-6',3), 7.866 (d, 1H, H-2), 7.666 (m, 3H, H-2"', 6"',6), 7.596 (m, 2H, H-3",5"), 7.489 (m, 3H, H-3"', 4"', 5"'), 7.379 (m, 2H, H-4",6"), 6.875 (d, 1H, H-5); ${ }^{13} \mathrm{C}$ NMR $\delta$ ppm 189.356 (C-1), 164.235 (C-4), 162.368 (C-2"), 141.026 (C-3), 140.225 (C-6), 138.288 (C-1'), 135.938 (C-3'), 135.010 (C-1"'), 133.065 (C-5'), 130.286 (C-4"), 129.820 (C-4"',6"), 129.430 (C-3"',5"'), 128.179 (C-2"',6"'), 125.418 (C4'), 124.727 (C-5"), 124.301 (C-6'), 124.103 (C-1"), 122.612 (C-2), 122.351 (C-2'), 119.195 (C-5), 116.456 (C$3 ")$.

\section{1-(3'-cinnamaamidophenyl)-3-(3"-fluorophenyl)-prop-2-en-1-one (2f)}

Yellow colored solid, yield (93.52\%). mp: $155^{\circ} \mathrm{C}$; FTIR ( $\left.\mathrm{KBr}, \mathrm{cm}-1\right)$ : 3340.15 ( $\mathrm{N}-\mathrm{H}$ stretch of anilide), 1662.49 ( $\mathrm{C}=0$ stretch of anilide), $1612.49(\mathrm{C}=0$ stretch of $\mathrm{a}, \beta$ unsaturated ketone), 1514.12 (aromatic $\mathrm{C}=\mathrm{C}$ stretch); ${ }^{1} \mathrm{H}_{\mathrm{NMR}}\left(\mathrm{DMSO}_{-} \mathrm{d}_{6}, \delta \mathrm{ppm}\right): 10.477$ (s, $\left.1 \mathrm{H}, \mathrm{NH}\right), 8.376$ (s, 1H, H-2'), 8.078 (d, 1H, H-4'), 7.971 (m, 


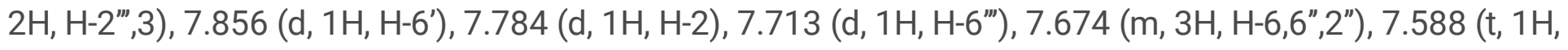
$\left.\mathrm{H}-5^{\prime}\right), 7.535$ (m, 4H, H-3"', 4"', 5"',4"), 7.320 (t, 1H, H-5"), 6.884 (d, 1H, H-5); ${ }^{13} \mathrm{C}$ NMR $\delta$ ppm 189.427 (C-1), 164.214 (C-4), 161.920 (C-3"), 142.989 (C-3), 140.988 (C-6), 140.184 (C-1'), 138.370 (C-1")), 137.633 (C-3'), 135.021 (C-1"'), 131.243 (C-5'), 130.228 (C-5"), 129.701 (C-4"'), 129.386 (C-3"', 5"'), $128.153\left(\mathrm{C}-2^{\prime \prime \prime}, 6^{\prime \prime \prime}\right)$, 125.784 (C-4'), 124.309 (C-6'), 123.994 (C-6"), 122.382 (C-2), 119.256 (C-2'), 117.738 (C-5), 115.152 (C-4"), $114.977\left(\mathrm{C}-2^{\prime \prime}\right)$.

\section{1-(3'-cinnamaamidophenyl)-3-(4"-fluorophenyl)-prop-2-en-1-one (2g)}

Yellow (very light) colored solid, yield (79.13\%). mp:168 ${ }^{\circ} \mathrm{C}$; FTIR ( $\left.\mathrm{KBr}, \mathrm{cm}-1\right)$ : $3344.52(\mathrm{~N}-\mathrm{H}$ stretch of anilide), 3001.17 (aromatic $\mathrm{C}-\mathrm{H}$ stretch), 1658.78 ( $\mathrm{C}=\mathrm{O}$ stretch of anilide), 1612.49 (C=O stretch of $\mathrm{a}, \beta$ unsaturated ketone), 1514.12 (aromatic $\mathrm{C}=\mathrm{C}$ stretch); ${ }^{1} \mathrm{H}$ NMR (DMSO- $\left.\mathrm{d}_{6}, \delta \mathrm{ppm}\right): 10.469(\mathrm{~s}, 1 \mathrm{H}, \mathrm{NH})$, 8.359 (s, 1H, H-2'), 8.057 (d, 1H, H-4'), 7.995 (m, 3H, H-2', 6"', $\left.6^{\prime}\right), 7.867$ (d, 1H, H-3), 7.793 (d, 1H, H-2), 7.664 (m, 3H, H-6,2",6"), $7.583\left(\mathrm{t}, 1 \mathrm{H}, \mathrm{H}-5^{\prime}\right), 7.485\left(\mathrm{~m}, 3 \mathrm{H}, \mathrm{H}-3^{\prime \prime \prime}, 4^{\prime \prime \prime}, 5^{\prime \prime}\right), 7.346\left(\mathrm{~m}, 2 \mathrm{H}, \mathrm{H}-3^{\prime \prime}, 5^{\prime \prime}\right), 6.876(\mathrm{~d}, 1 \mathrm{H}, \mathrm{H}-5) ;{ }^{13} \mathrm{C}$ NMR $\delta$ ppm 189.421 (C-1), 164.198 (C-4), 162.835 (C-4"), 143.275 (C-3), 140.969 (C-6), 140.153 (C-1'), 138.533 (C-3'), 135.013 (C-1"'), 131.696 (C-5'), 131.579 (C-2",6"), 131.516 (C-1"), 130.241 (C-4"'), 129.692 (C-4'), 129.398 (C-3"', 5"'), 128.153 (C-2"',6"'), 124.137 (C-6'), 122.385 (C-2',2), 119.197 (C-5), 116.430 (C-5"), $116.257\left(\mathrm{C}-3^{\prime \prime}\right)$.

\section{1-(3'-cinnamaamidophenyl)-3-(2"-chlorophenyl)-prop-2-en-1-one (2h)}

Buff colored solid, yield (89.65\%). mp:167 $\mathrm{C}$; FTIR ( $\mathrm{KBr}, \mathrm{cm}-1)$ : 3344.52 (N-H stretch of anilide), 3001.17 (aromatic $\mathrm{C}-\mathrm{H}$ stretch), 1658.78 ( $\mathrm{C}=\mathrm{O}$ stretch of anilide), 1612.49 ( $\mathrm{C}=\mathrm{O}$ stretch of $\mathrm{a}, \beta$ unsaturated ketone), 1514.12 (aromatic $\mathrm{C}=\mathrm{C}$ stretch); ${ }^{1} \mathrm{H}$ NMR (DMSO-d $\left.{ }_{6}, \delta \mathrm{ppm}\right): 10.308(\mathrm{~s}, 1 \mathrm{H}, \mathrm{NH}), 8.215\left(\mathrm{~s}, 1 \mathrm{H}, \mathrm{H}-2^{\prime}\right), 8.043$ (d, 1H, H-4'), 7.915 (m, 2H, H-2"',3), 7.799 (m, 2H, H-6"',2), 7.504 (m, 2H, H-5',6'), 7.446 (m, 3H, H-6, 3", 5"), $7.363\left(\mathrm{~m}, 5 \mathrm{H}, \mathrm{H}-3^{\prime \prime \prime}, 4^{\prime \prime \prime}, 5^{\prime \prime}, 4^{\prime \prime}, 6^{\prime \prime}\right), 6.717$ (d, 1H, H-5); ${ }^{13} \mathrm{C}$ NMR $\delta$ ppm 189.291 (C-1), 164.215 (C-4), 141.016 (C-3), 140.215 (C-6), 139.049 (C-1'), 138.228 (C-3'), 135.002 (C-1"'), 134.741 (C-2"), 132.649 (C-5'), 132.437 (C-1"), 130.460 (C-3"), 130.276 (C-4"), 129.787 (C-4"'), 129.421 (C-3"', 5"'), 128.925 (C-6",4'), 128.164 (C$\left.2^{\prime \prime \prime}, 6^{\prime \prime \prime}\right), 125.286\left(\mathrm{C}-5^{\prime \prime}\right), 124.401\left(\mathrm{C}-6^{\prime}\right), 124.283$ (C-2), 122.342 (C-2'), 119.206 (C-5).

\section{1-(3'-cinnamaamidophenyl)-3-(3"-chlorophenyl)-prop-2-en-1-one (2i)}

White (pale) colored solid, yield (75.86\%). mp:165² $\mathrm{FTIR}(\mathrm{KBr}, \mathrm{cm}-1)$ : 3321.81 (N-H stretch of anilide), 1664.57 ( $C=0$ stretch of anilide), 1612.49 ( $C=0$ stretch of $a, \beta$ unsaturated ketone), 1514.12 (aromatic $\mathrm{C}=\mathrm{C}$ stretch), 761.88 (C-Cl stretch); ${ }^{1} \mathrm{H}$ NMR (DMSO-d $\left.{ }_{6}, \delta \mathrm{ppm}\right): 10.595(\mathrm{~s}, 1 \mathrm{H}, \mathrm{NH}), 8.489\left(\mathrm{~s}, 1 \mathrm{H}, \mathrm{H}-2^{\prime}\right)$, 8.206 (m, 2H, H-4', 2"'), 8.121 (m, 2H, H-6"',3), 7.980 (d, 1H, H-6'), 7.898 (d, 1H, H-2), 7.797 (m, 3H, H-6, 5',6"), $7.724\left(\mathrm{t}, 1 \mathrm{H}, \mathrm{H}-5^{\prime \prime}\right), 7.674$ (m, 5H, H-3"', $\left.4^{\prime \prime \prime}, 5^{\prime \prime}, 4^{\prime \prime}, 2^{\prime \prime}\right), 7.010$ (d, 1H, H-5); ${ }^{13} \mathrm{C}$ NMR $\delta$ ppm 189.405 (C-1), 164.194 (C-4), 142.771 (C-3), 140.998 (C-6), 140.158 (C-1'), 138.345 (C-3',1"), 137.302 (C-1"'), 135.007 (C3"), 134.207 (C-5'), 131.110 (C-5”), 130.583 (C-4"), 130.280 (C-4"'), 129.743 (C-4'), 129.430 (C-3"', $\left.5^{\prime \prime \prime}\right)$, 128.368 (C-6'), $128.165\left(\mathrm{C}-2^{\prime \prime}, 6^{\prime \prime}\right), 124.338\left(\mathrm{C}-2^{\prime \prime}, 6^{\prime \prime}\right), 124.086$ (C-2), 122.351 (C-2'), 119.220 (C-5). 
1-(3'-cinnamaamidophenyl)-3-(4"-chlorophenyl)-prop-2-en-1-one (2j)

Brown (pale) colored solid, yield (82.75\%). mp:182 ${ }^{\circ} \mathrm{C} ; \mathrm{FTIR}(\mathrm{KBr}, \mathrm{cm}-1): 3429.43$ ( $\mathrm{N}-\mathrm{H}$ stretch of anilide), 1656.85 ( $C=0$ stretch of anilide), 1612.49 ( $C=0$ stretch of $a, \beta$ unsaturated ketone), 1514.12 (aromatic $\mathrm{C}=\mathrm{C}$ stretch), 750.31 (C-Cl stretch); ${ }^{1} \mathrm{H}$ NMR (DMSO-d ${ }_{6}, \delta$ ppm): 10.379 (s, 1H, NH), $8.212\left(\mathrm{~s}, 1 \mathrm{H}, \mathrm{H}-2^{\prime}\right)$, 7.901 (d, 1H, H-4'), 7.787 (m, 4H, H-2"', 6"',6',3), 7.616 (d, 1H, H-2), 7.500 (m, 3H, H-6,2",6"), 7.422 (m, 3H, H$\left.5^{\prime}, 3^{\prime \prime}, 5^{\prime \prime}\right), 7.326$ (m, 3H, H-3"', $\left.4^{\prime \prime \prime}, 5^{\prime \prime \prime}\right), 6.737$ (d, 1H, H-5); ${ }^{13} \mathrm{C}$ NMR $\delta$ ppm 189.432 (C-1), 164.227 (C-4), 143.027 (C-3), 140.921 (C-6), 140.205 (C-1'), 138.426 (C-3'), 135.535 (C-1"'), 135.022 (C-5'), 134.009 (C-4"), 130.916 (C-2",6"), 130.260 (C-1"), 129.723 (C-4"',4'), 129.411 (C-3"', 5"',3",5"), $128.163\left(\mathrm{C}-2^{\prime \prime \prime}, 6^{\prime \prime \prime}\right), 124.235$ (C6'), 123.301 (C-2), 122.433 (C-2'), $119.224(\mathrm{C}-5)$.

\section{1-(3'-cinnamaamidophenyl)-3-(3", 4"-dichlorophenyl)-prop-2-en-1-one (2k)}

White (pale) colored solid, yield (63.49\%). mp:180 $\mathrm{C}$; FTIR (KBr, cm-1): 3340.84 (N-H stretch of anilide), 3064.64 (aromatic $\mathrm{C}-\mathrm{H}$ stretch), 1651.7 (C=O stretch of $\mathrm{a}, \beta$ unsaturated ketone), 750.08 (C-Cl stretch); ${ }^{1} \mathrm{H}$ NMR (DMSO-d ${ }_{6}, \delta$ ppm): $10.472(\mathrm{~s}, 1 \mathrm{H}, \mathrm{NH}), 8.350$ (s, 1H, H-2'), 8.069 (d, 1H, H-4'), $8.026\left(\mathrm{~m}, 2 \mathrm{H}, \mathrm{H}-2^{\prime \prime}, 3\right)$, 7.904 (d, 1H, H-6'), 7.757 (m, 2H, H-6"',2), 7.661 (m, 4H, H-6,2",5",6"), $7.592\left(\mathrm{t}, 1 \mathrm{H}, \mathrm{H}-5^{\prime}\right), 7.487(\mathrm{~m}, 3 \mathrm{H}, \mathrm{H}-$ $\left.3^{\prime \prime \prime}, 4^{m \prime}, 5^{\prime \prime \prime}\right), 6.874$ (d, 1H, H-5); ${ }^{13} \mathrm{C}$ NMR $\delta$ ppm 189.248 (C-1), 164.188 (C-4), 141.654 (C-3), 140.979 (C-6), $140.176\left(C-1^{\prime}\right), 138.269$ (C-3'), $135.913\left(C^{\prime}-1^{\prime \prime}\right), 135.006(C-1 "), 133.159\left(C-5^{\prime}\right), 132.237\left(C-3^{\prime \prime}\right), 131.371$ (C4"), 130.563 (C-4"',2"), 130.252 (C-5"), 129.699 (C-4',6"), 129.400 (C-3"', 5"), 128.155 (C-2"', 6"'), 124.533 (C6'), 124.383 (C-2), 122.357 (C-2'), 119.207 (C-5).

\section{1-(3'-cinnamaamidophenyl)-3-(3"-nitrophenyl)-prop-2-en-1-one (2l)}

White (pale) colored solid, yield (80.53\%). mp:205 C; FTIR ( $\mathrm{KBr}, \mathrm{cm}-1)$ : 3317.56 (N-H stretch of anilide), 1662.64 ( $C=0$ stretch of anilide), 1612.49 ( $C=0$ stretch of $\alpha, \beta$ unsaturated ketone), 1514.12 (aromatic $\mathrm{C}=\mathrm{C}$ stretch), $1346.31\left(\mathrm{NO}_{2}\right.$ stretch); ${ }^{1} \mathrm{H}$ NMR (DMSO-d $\left.{ }_{6}, \delta \mathrm{ppm}\right): 10.500(\mathrm{~s}, 1 \mathrm{H}, \mathrm{NH}), 8.801\left(\mathrm{~s}, 1 \mathrm{H}, \mathrm{H}-2^{\prime \prime}\right)$, $8.383\left(\mathrm{~m}, 2 \mathrm{H}, \mathrm{H}-2^{\prime}, 4^{\prime \prime}\right), 8.319$ (d, 1H, H-4'), 8.146 (d, 1H, H-3), 8.085 (d, 1H, H-6"), 8.041 (d, 1H, H-6'), 7.925 (d, $1 \mathrm{H}, \mathrm{H}-2), 7.809$ (t, 1H, H-5"), 7.675 (m, 3H, H-2"',6"',6), 7.619 (t, 1H, H-5'), 7.503 (m, 3H, H-3"', 4"', 5"'), 6.892 (d, $1 \mathrm{H}, \mathrm{H}-5$ ); ${ }^{13} \mathrm{C}$ NMR $\delta$ ppm 189.382 (C-1), 166.270 (C-4), 148.921 (C-3"), 142.051 (C-6,3), 140.243 (C-1"), $138.212\left(\mathrm{C}-1^{\prime}\right), 137.061$ (C-3'), 135.503 (C-1"',6"), 135.097 (C-5'), 132.286 (C-5"), 130.864 (C-4"'), 129.679 (C-4'), 128.935 (C-3"', $\left.5^{\prime \prime \prime}\right), 128.223$ (C-2"',6"'), 125.684 (C-6'), 125.345 (C-2", 4"), 124.804 (C-2), 123.551 (C-2'), $120.673(\mathrm{C}-5)$.

\section{1-(3'-cinnamaamidophenyl)-3-(4"-nitrophenyl)-prop-2-en-1-one (2m)}

Buff colored solid, yield (83.89\%). mp:207 C; FTIR ( $\mathrm{KBr}, \mathrm{cm}-1)$ : 3329.14 ( $\mathrm{N}-\mathrm{H}$ stretch of anilide), 1664.57 ( $C=0$ stretch of anilide), 1612.49 ( $C=0$ stretch of $a, \beta$ unsaturated ketone), 1510.26 (aromatic $C=C$ stretch), $1344.38\left(\mathrm{NO}_{2}\right.$ stretch); ${ }^{1} \mathrm{H}$ NMR (DMSO-d $\left.6, \delta \mathrm{ppm}\right): 10.320(\mathrm{~s}, 1 \mathrm{H}, \mathrm{NH}), 8.223\left(\mathrm{~s}, 1 \mathrm{H}, \mathrm{H}-2^{\prime}\right), 8.159$ (d, 2H, H-3",5"), 8.025 (d, 2H, H-2",6"), 7.928 (m, 2H, H-4',3), 7.826 (d, 1H, H-6'), 7.707 (d, 1H, H-2), 7.501 (m, $\left.3 \mathrm{H}, \mathrm{H}-6,2^{\prime \prime \prime}, 6^{\prime \prime \prime}\right), 7.444\left(\mathrm{t}, 1 \mathrm{H}, \mathrm{H}-5^{\prime \prime}\right), 7.327\left(\mathrm{~m}, 3 \mathrm{H}, \mathrm{H}-3^{\prime \prime \prime}, 4^{4 \prime \prime}, 5^{\prime \prime \prime}\right), 6.716(\mathrm{~d}, 1 \mathrm{H}, \mathrm{H}-5) ;{ }^{13} \mathrm{C}$ NMR $\delta$ ppm 189.393 (C- 
1), 164.215 (C-4), 148.518 (C-4"), 141.624 (C-3), 141.509 (C-6), 141.025 (C-1"), 140.215 (C-1'), 138.137 (C-

3'), 134.987 (C-1"', 5'), 130.269 (C-4"'), 130.209 (C-2", 6"), 129.813 (C-4'), 129.430 (C-3"', 5"'), 128.167 (C-

$\left.2^{\prime \prime \prime}, 6^{\prime \prime \prime}\right), 126.566$ (C-6'), 124.508 (C-2), 124.355 (C-3",5"), 122.322 (C-2'), 119.229 (C-5).

\section{Biological Assay}

\section{Antiproliferative activity by Sulforhodamine B (SRB) assay}

The in-vitro anticancer activity was measured for synthesized new compounds on breast cancer (MCF-7), chronic myelogenous leukemias (K562), glioblastoma (U373MG), and colon cancer (HT-29) using the Sulforhodamine-B stain (SRB) assay. The cell lines were grown in RPMI 1640 medium containing 10\% fetal bovine serum and $2 \mathrm{mM}$ L-glutamine. For the screening experiment, cells were inoculated into 96 well microtiter plates in $100 \mu \mathrm{L}$ at plating densities as shown in the study details above, depending on the doubling time of individual cell lines. After cell inoculation, the microtiter plates were incubated at $37^{\circ} \mathrm{C}$, $5 \% \mathrm{CO}_{2}, 95 \%$ air and $100 \%$ relative humidity for $24 \mathrm{~h}$ prior to addition of experimental compounds. After $24 \mathrm{~h}$, one 96 well plate containing $5 \times 10^{3}$ cells/well was fixed in situ with trichloroacetic acid (TCA), to represent a measurement of the cell population at the time of drug addition (Tz). Experimental compounds were initially solubilized in DMSO at $100 \mathrm{mg} / \mathrm{ml}$ and diluted to $1 \mathrm{mg} / \mathrm{ml}$ using water and stored frozen prior to use. At the time of addition, an aliquot of frozen concentrate $(1 \mathrm{mg} / \mathrm{ml})$ was thawed and diluted to $10^{-6}, 10^{-5}, 10^{-4}$ and $10^{-3} \mu \mathrm{g} / \mathrm{ml}$ with complete medium containing test compounds. Aliquots of $10 \mu \mathrm{l}$ of these different compound dilutions were added to the appropriate microtiter wells already containing $90 \mu \mathrm{l}$ of medium, resulting in the required final concentrations i.e. $10^{-7}, 10^{-6}, 10^{-5}, 10^{-4} \mathrm{M}$. After the addition, plates were incubated at standard conditions for $48 \mathrm{~h}$ and assay was terminated by the addition of cold TCA. Cells were fixed in situ by the gentle addition of $50 \mu \mathrm{l}$ of cold $30 \%(\mathrm{w} / \mathrm{v}$ ) TCA (final concentration, $10 \% \mathrm{TCA}$ ) and incubated for $60 \mathrm{~min}$ at $4^{\circ} \mathrm{C}$. The supernatant was discarded; plates were washed five times with tap water and air dried. SRB solution $(50 \mu \mathrm{l})$ at $0.4 \%(\mathrm{w} / \mathrm{v})$ in $1 \%$ acetic acid was added to each of the wells, and plates were incubated for $20 \mathrm{~min}$ at room temperature. After staining, unbound dye was recovered and the residual dye was removed by washing five times with $1 \%$ acetic acid. The plates were air dried. Bound stain was subsequently eluted with $10 \mathrm{mM}$ trizma base, and the absorbance was read on a plate reader at a wavelength of $540 \mathrm{~nm}$ with $690 \mathrm{~nm}$ reference wavelength. Percent growth was calculated on a plate-by-plate basis for the test wells relative to the control wells, and expressed as the ratio of average absorbance of the test wells to the average absorbance of the control wells $\times 100[43,44]$.

Using the six absorbance measurements [time zero (Tz), control growth (C), and test growth in the presence of drug at the four concentration levels $(\mathrm{Ti})$ ], the percentage growth was calculated at each of the drug concentration levels. Percentage growth inhibition was calculated as:

$[(\mathrm{Ti}-\mathrm{Tz}) /(\mathrm{C}-\mathrm{Tz})] \times 100$ for concentrations for which $\mathrm{Ti}>/=\mathrm{Tz}(\mathrm{Ti}-\mathrm{Tz})$ positive or zero

$[(\mathrm{Ti}-\mathrm{Tz}) / \mathrm{Tz}] \times 100$ for concentrations for which $\mathrm{Ti}<\mathrm{Tz}$. (Ti-Tz) negative 


\section{CDK2 and EGFR Kinase Inhibition Assay by ADP Glo ${ }^{\mathrm{TM}}$ Assay}

Kinase activities were performed using CDK2/CyclinA2 Kinase (Promega; Catalog \#V2971), EGFR Kinase (Promega; Catalog \#V3831), and ADP-Glo Kinase Assay kit (Promega; Catalog \#V9101). Kinase enzyme kit contained Active enzyme, substrate, Reaction Buffer A (5X) and DTT solution (0.1M). Additionally, $\mathrm{MnCl}_{2}$ solution (2.5M) in EGFR kinase system. Reaction Buffer A (5X) was composed of $200 \mathrm{mM}$ Tris- $\mathrm{HCl}$, $\mathrm{pH}$ 7. $5,100 \mathrm{mM} \mathrm{MgCl}_{2}$ and $0.5 \mathrm{mg} / \mathrm{ml} \mathrm{BSA}$. ADP Glo kinase kit contained UltraPure ATP (10mM), ADP-Glo Reagent, Kinase Detection Buffer and Kinase Detection Substrate.

ADP-Glo Reagents were thawed at room temperature. Kinase Detection Reagent was prepared by mixing Kinase Detection Buffer with the Lyophilized Kinase Detection Substrate. Components of CDK2 and EGFR enzyme systems were thawed on ice. $2 X$ buffer was prepared from Reaction Buffer $A$ as given in protocol i.e. $1 \mathrm{ml}$ of $2 X$ Buffer by combining $400 \mu \mathrm{l}$ Reaction Buffer $\mathrm{A}, 1 \mu \mathrm{L}$ DTT and $599 \mu \mathrm{l}$ of distilled $\mathrm{H}_{2} \mathrm{O}$ for CDK2 system. Similarly, $2 X$ buffer was prepared from the Reaction Buffer A for EGFR system in the following manner: $1 \mathrm{ml}$ of $2 X$ Buffer by combining $400 \mu$ l Reaction Buffer $\mathrm{A}, 1 \mu \mathrm{LTT}, 1.6 \mu \mathrm{MnCl}_{2}$ and $597.4 \mu \mathrm{l}$ of distilled $\mathrm{H}_{2} \mathrm{O}$. Further, $1 \mathrm{X}$ buffer was prepared for both the systems by diluting corresponding $2 \mathrm{X}$ buffer with distilled water in $1: 2$ ratio. $1 \mathrm{ml}$ of $250 \mu \mathrm{M}$ ATP Assay Solution was prepared by adding $25 \mu \mathrm{l}$ ATP solution (10mM) to $500 \mu \mathrm{l}$ of $2 \mathrm{X}$ Buffer and $475 \mu \mathrm{l}$ of distilled $\mathrm{H}_{2} \mathrm{O}$.

Reactions were performed in solid white 96-well polystyrene flat-bottomed plates in a final volume of $100 \mu \mathrm{L}$. First step was to optimize the enzyme concentration. Different concentrations of enzymes were prepared in $1 X$ Buffer. Reaction mixtures contained $10 \mu \mathrm{L}$ of diluted Active enzyme, $5 \mu \mathrm{L}$ of $1 \mathrm{mg} / \mathrm{ml}$ stock solution of enzyme substrate ((Poly $\left(\mathrm{Glu}_{4}, \mathrm{Tyr}_{1}\right)$ peptide substrate for EGFR system and Histone $\mathrm{H} 1$ substrate for CDK2 system) and $5 \mu \mathrm{L}$ of $2 \mathrm{X}$ Buffer. Further, $5 \mu$ l of $250 \mu \mathrm{M}$ ATP assay solution was added in each well. After addition of ATP solution, the plates were incubated at $30^{\circ} \mathrm{C}$ for 15 minutes. The reactions were terminated by adding $25 \mu \mathrm{l}$ of ADP-Glo Reagent. Plates were shaken and then incubated for another 40 minutes at room temperature. After incubation, 50 $\mu$ of the Kinase Detection Reagent was added, followed by incubation for another 30 minutes at room temperature. Luminescence was read using Microplate luminometer. The conversion curve (RLU vs $\log _{10}$ [Enzyme concentration], ng) was plotted and corresponding signal-to-background ratio (SB) was calculated.

For screening of enzyme inhibitors, drugs were initially solubilized in dimethyl sulfoxide (DMSO) and diluted using distilled $\mathrm{H}_{2} \mathrm{O}$. Three different concentrations were prepared viz. $1 \mu \mathrm{M}, 3 \mu \mathrm{M}$ and $10 \mu \mathrm{M}$ (concentration of DMSO in an assay does not exceed $2 \%$ ). $5 \mu \mathrm{L}$ of different drug concentrations were added to the initial reaction mixture instead of $2 X$ Buffer and reaction was carried out as done during enzyme optimization. Using the relative light units [RLUs] in the presence of drug at three different concentration levels, the percentage enzyme activity was calculated at each concentration of the compound tested. The $\mathrm{IC}_{50}$ values were calculated from a plot of the percentage enzyme activity vs. log concentration of the compounds $[32,45]$.

\section{In-silico Computational Studies}




\section{Molecular docking}

Molecular docking studies were done using Glide version 5.9 software $[46,47]$ in Schrodinger suite 20171. The crystal structure used for the studies were downloaded from protein data bank. These included PDB 2WXV for CDK2 [31] and PDB 1M17 for EGFR [48, 49]. These are complexed with inhibitor with ligand identifier WXV and AQ4; respectively. The protein structures were refined using the protein preparation wizard. All the water molecules that did not form any interactions or were not a part of the active site were deleted. Hydrogen atoms were added to the protein which included the protons necessary to define the correct ionization and tautomeric states of the amino acid residues. The protein structure was energy minimized using the impact refinement module. The steric clashes existing in the structures were removed using OPLS 2005 force field [50]. After protein prepartion, the receptor grids were generated using the receptor grid generation panel for CDK2 and EGFR, individually. The protein structures for CDK2 and EGFR were included as workspace entries and their ligands WXV and AQ4 were picked to be excluded from receptor grid generation using the 'receptor' tab. Default vdW scaling factor of 1.0 and charge scale factor of 0.25 were used. The centroid of co-crystallized ligand was used for the grid generation and the size for the ligands to be docked should be similar to the co-crystallized ligand. According to these specifications for the center and size the final grid was generated. No constraints were used [51]. The docking protocol was validated for both CDK2 and EGFR by removing the inhibitors from their complexes, re-docking, and calculating root mean square deviation (RMSD). The ligands were prepared using ligprep module [52] of Schordinger at $\mathrm{pH} 7.4$ and then used for docking. The 2D ligand interaction diagrams for the docked complexes were visualized using the Maestro in Schrodinger suite 2016-4.

\section{Molecular Dynamics Simulation}

\section{System Building}

All molecular dynamics (MD) simulations were performed using the Desmond software [53, 54]. The initial coordinates for the MD simulations were taken from the docked complexes for compounds $2 \mathrm{I}$ and $2 \mathrm{k}$ with CDK2. The orthorhombic box with dimensions $10 \AA \times 10 \AA \times 10 \AA$ approximately was used to apply the periodic boundary conditions. The TIP3P water molecules [55] were then added and the system was neutralized to balance the net charge of the system. Equilibration of the system was carried out using the default protocol provided in Desmond Software with OPLS2005 force field [56]. The equilibration consisted of a series of restrained minimizations that slowly relax the system without deviating substantially from the initial protein coordinates.

\section{Simulation Details}

Force field parameters for the protein-ligand systems were assigned using the OPLS-2005 force field. Heavy atom bond lengths with hydrogens and the internal geometry of water molecules were constrained using the SHAKE algorithm [57]. Periodic boundary conditions and a 9.0A cut-off for non-bond interactions was used, with electrostatic interactions treated using the particle mesh ewald method. A default six-stage relaxation protocol was employed prior to the MD production run: (i) 2000 steps limited- 
memory Broyden-Fletcher-Goldfarb-Shanno (LBFGS) minimization (first 10 steps steepest descent algorithm) with the solute restrained and a loose convergence criterion of $50 \mathrm{kcal} \mathrm{mol}^{-1} \AA^{-1}$; (ii) $2000 \mathrm{steps}$ LBFGS minimization (first 10 steps steepest descent) with residues beyond $15 \AA$ of ligands restrained and a convergence criterion of $5 \mathrm{kcal} \mathrm{mol}^{-1} \AA^{-1}$. (iii) a short $12 \mathrm{ps}$ simulation in the NVT ensemble using a temperature $(\mathrm{T})$ of $10 \mathrm{~K}$ (thermostat relaxation constant $=0.1 \mathrm{ps}$ ) with non-hydrogen solute atoms restrained; (iv) a 12 ps simulation in the NPT ensemble using $\mathrm{T}=10 \mathrm{~K}$ (thermostat relaxation constant = $0.1 \mathrm{ps}$ ) and pressure $\mathrm{P}=1 \mathrm{~atm}$ (barostat relaxation constant= $50 \mathrm{ps}$ ) with non-hydrogen solute atoms restrained; $(v)$ a 24 ps simulation in the NPT ensemble ( $T=300 \mathrm{~K}$; thermostat relaxation constant $=0.1 \mathrm{ps;}$ $\mathrm{P}=1 \mathrm{~atm}$; barostat relaxation constant $=50.0 \mathrm{ps}$ ) with solute non-hydrogen atoms restrained; and (vi) a $24 \mathrm{ps}$ simulation in the NPT ensemble $(T=300 \mathrm{~K}$; thermostat relaxation constant $=0.1 \mathrm{ps} ; \mathrm{P}=1 \mathrm{~atm}$; barostat relaxation constant $=2.0 \mathrm{ps}$ ) with residues beyond $15 \AA$ of the ligands restrained. For all of the aforementioned atomic restraints, a $50 \mathrm{kcal} \mathrm{mol}^{-1} \AA^{-1} 2$ restraint force constant was used, whereas target temperatures and pressures were controlled using Berendsen thermostat and barostat, respectively. For the dynamics, a multiple time step RESPA integration algorithm was used throughout, with time steps of 2 , 2, and 6 fs for bonded, "near" non-bonded and "far" non-bonded interactions, respectively. Following the relaxation, a $20 \mathrm{~ns}$ MD run in the NPT ensemble was performed for each system using a NoseHoover thermostat and Martyna-Tobias-Klein barostat $(T=300 \mathrm{~K}$, thermostat relaxation time $=1.0 \mathrm{ps} ; \mathrm{P}$ $=1 \mathrm{~atm}$; barostat relaxation time $=2.0 \mathrm{ps}$ ). Energy and trajectory atomic coordinate data were recorded at every 1.2 and 20.0 ps; respectively. An approximate number of 1000 frames were recorded [58, 59].

\section{Declarations}

\section{Acknowledgements}

This work was funded by Department of Biotechnology under the F. No. BT/PR14373/Med/30/530/210. Akshada Joshi acknowledges the Junior Research Fellowship provided to her by Department of Biotechnology (F. No. BT/PR14373/Med/30/530/210). Urmila J. Joshi acknowledges the funding provided by All India Council for Technical Education (AICTE) for the sanction of the molecular docking software Glide with other modules under the Research Promotion Scheme (F. No. 8-36/RIFD/RPS/Policy1/2017-18). The authors would also like to thank Department of Science and Technology under the DSTFIST Funding Letter SR/FST/College-264 for the computational facility. The authors acknowledge ACDSF unit at ACTREC, Khargar, Navi-Mumbai for providing in-vitro antiproliferative activity testing services. We also acknowledge Desmond Molecular Dynamics System, D. E. Shaw Research, New York, NY, 2016.

\section{Conflicts of interest/Competing interests}

The authors have no potential conflict of interest.

\section{Supplementary Information}

Supplementary material is available on the publisher's web site along with the published article 


\section{References}

1. Bayliss R, Fry A, Haq T, Yeoh S. On the molecular mechanisms of mitotic kinase activation. Open biology. 2012; 2(11):120136. https://doi.org/10.1098/rsob.120136

2. Shapiro GI. Cyclin-dependent kinase pathways as targets for cancer treatment. J Clin Oncol. 2006; 24(11):1770-1783. https://doi.org/10.1200/JC0.2005.03.7689

3. Santo L, Siu KT, Raje N. Targeting cyclin-dependent kinases and cell cycle progression in human cancers. Seminars in oncology. 2015; 42(6): 788-800.

https://doi.org/10.1053/j.seminoncol.2015.09.024

4. Tadesse S, Anshabo AT, Portman N, Lim E, Tilley W, Caldon CE, Wang S. Targeting CDK2 in cancer: challenges and opportunities for therapy. Drug discovery today. 2019; 25(2):406-13. https://doi.org/10.1016/j.drudis.2019.12.001

5. Tadesse S, Caldon EC, Tilley W, Wang S. Cyclin-dependent kinase 2 inhibitors in cancer therapy: an update. J Med Chem. 2018; 62(9):4233-4251. https://doi.org/10.1021/acs.jmedchem.8b01469

6. Ravishankar D, Rajora AK, Greco F, Osborn HM. Flavonoids as prospective compounds for anticancer therapy. Int J Biochem Cell Biol. 2013; 45(12):2821-2831. https://doi.org/10.1016/j.biocel.2013.10.004

7. Kuntz S, Wenzel U, Daniel H. Comparative analysis of the effects of flavonoids on proliferation, cytotoxicity, and apoptosis in human colon cancer cell lines. Eur J Nutr . 1999; 38(3):133-42. https://doi.org/10.1007/s003940050054

8. Paier CR, Maranhão SS, Carneiro TR, Lima LM, Rocha DD, Santos RD, Farias KM, Moraes-Filho MO, Pessoa C. Natural products as new antimitotic compounds for anticancer drug development. Clinics . 2018; 73. https://doi.org/10.6061/clinics/2018/e813s

9. Ren W, Qiao Z, Wang H, Zhu L, Zhang L. Flavonoids: promising anticancer agents. Med Res Rev. 2003; 23(4):519-534. https://doi.org/10.1002/med.10033

10. Tuli HS, Tuorkey MJ, Thakral F, Sak K, Kumar M, Sharma AK, Sharma U, Jain A, Aggarwal V, Bishayee A. Molecular mechanisms of action of genistein in cancer: Recent advances. Front Pharmacol. 2019; 10:1336. https://doi.org/10.3389/fphar.2019.01336

11. Shukla S, Gupta S. Apigenin: a promising molecule for cancer prevention. Pharm Res. 2010; 27(6):962-978. https://doi.org/10.1007/s11095-010-0089-7

12. De Azevedo WF, Mueller-Dieckmann HJ, Schulze-Gahmen U, Worland PJ, Sausville E, Kim SH. Structural basis for specificity and potency of a flavonoid inhibitor of human CDK2, a cell cycle kinase. Proceedings of the National Academy of Sciences. 1996; 93(7):2735-2740. https://doi.org/10.1073/pnas.93.7.2735

13. Wagal OS, Joshi AJ, Joshi UJ, Bhojwani HR, Begwani KV, Dawne HA, Gude RP, Sathaye SS, Kanchan DM. Studies in molecular modeling, in-vitro CDK2 inhibition and antimetastatic activity of some synthetic flavones. Front Biosci (Landmark Ed). 2021; 26:664-681. 
14. Kasi PD, Tamilselvam R, Skalicka-Woźniak K, Nabavi SF, Daglia M, Bishayee A, Pazoki-Toroudi H, Nabavi SM. Molecular targets of curcumin for cancer therapy: an updated review. Tumor Biol. 2016; 37(10):13017-13028. https://doi.org/10.1007/s13277-016-5183-y

15. Latif NA, Batran RZ, Khedr MA, Abdalla MM. 3-Substituted-4-hydroxycoumarin as a new scaffold with potent CDK inhibition and promising anticancer effect: synthesis, molecular modeling and QSAR studies. Bioorg Chem. 2016; 67:116-129. https://doi.org/10.1016/j.bioorg.2016.06.005

16. J Leon-Gonzalez A, Acero N, Muñoz-Mingarro D, Navarro I, Martín-Cordero C. Chalcones as promising lead compounds on cancer therapy. Curr Med Chem. 2015; 22(30):3407-3425. https://doi.org/10.2174/0929867322666150729114829

17. De P, Baltas M, Bedos-Belval F. Cinnamic acid derivatives as anticancer agents-a review. Curr Med Chem. 2011; 18(11):1672-1703. https://doi.org/10.2174/092986711795471347

18. Silverstein RM, Bassler GC. Spectrometric Identification of Organic Compounds, $6^{\text {th }}$ ed., 2003, Jhon Wiley and Sons (Print Edition)

19. Carroll JS, Prall OW, Musgrove EA, Sutherland RL. A pure estrogen antagonist inhibits cyclin E-Cdk2 activity in MCF-7 breast cancer cells and induces accumulation of p130-E2F4 complexes characteristic of quiescence. Journal of Biological Chemistry. 2000; 275(49):38221-9. https://doi.org/10.1074/jbc.M004424200

20. Radosevic N, Delmer A, Tang R, Marie JP, Ajchenbaum-Cymbalista F. Cell cycle regulatory protein expression in fresh acute myeloid leukemia cells and after drug exposure. Leukemia. 2001;15(4):55966.

21. Zhu W, Sun C, Xu S, Wu C, Wu J, Xu M, Zhao H, Chen L, Zeng W, Zheng P. Design, synthesis, anticancer activity and docking studies of novel 4-morpholino-7, 8-dihydro-5H-thiopyrano [4, 3-d] pyrimidine derivatives as mTOR inhibitors. Bioorg Med Chem. 2014; 22(24):6746-6754. https://doi.org/10.1016/j.bmc.2014.11.003

22. Pawar CD, Chavan SL, Pawar UD, Pansare DN, Deshmukh SV, Shinde DB. Synthesis, anti-proliferative activity, SAR, and kinase inhibition studies of thiazol-2-yl-substituted sulfonamide derivatives. J Chin Chem Soc. 2019; 66(3):257-264. https://doi.org/10.1002/jccs.201800312

23. Gani OA, Engh RA. Protein kinase inhibition of clinically important staurosporine analogues. Nat Prod Rep. 2010; 27(4):489-498. https://doi.org/10.1039/b923848b

24. Chohan TA, Qian H, Pan Y, Chen JZ. Cyclin-dependent kinase-2 as a target for cancer therapy: progress in the development of CDK2 inhibitors as anti-cancer agents. Curr Med chem. 2015; 22(2):237-263. https://doi.org/10.1021/acs.jmedchem.8b01469

25. Carlino L, Christodoulou MS, Restelli V, Caporuscio F, Foschi F, Semrau MS, Costanzi E, Tinivella A, Pinzi L, Lo Presti L, Battistutta R. Structure-activity relationships of hexahydrocyclopenta [c] quinoline derivatives as allosteric inhibitors of CDK2 and EGFR. ChemMedChem. 2018; 13(24):2627-2634. https://doi.org/10.1002/cmdc.201800687

26. Stamos J, Sliwkowski MX, Eigenbrot C. Structure of the epidermal growth factor receptor kinase domain alone and in complex with a 4-anilinoquinazoline inhibitor. J Biol Chem. 2002; 
277(48):46265-46272. https://doi.org/10.1074/jbc.M207135200

27. Shewchuk L, Hassell A, Wisely B, Rocque W, Holmes W, Veal J, Kuyper LF. Binding mode of the 4anilinoquinazoline class of protein kinase inhibitor: X-ray crystallographic studies of 4anilinoquinazolines bound to cyclin-dependent kinase 2 and p38 kinase. J Med Chem. 2000; 43(1):133-138. https://doi.org/10.1021/jm990401t

28. Luk KC, Simcox ME, Schutt A, Rowan K, Thompson T, Chen Y, Kammlott U, DePinto W, Dunten $P$, Dermatakis A. A new series of potent oxindole inhibitors of CDK2. Bioorganic Med Chem Lett. 2004; 14(4):913-7. https://doi.org/10.1016/j.bmcl.2003.12.009

29. Maadwar S, Galla R. Cytotoxic oxindole derivatives: In vitro EGFR inhibition, pharmacophore modeling, 3D-QSAR and molecular dynamics studies. J Recept Signal Transduct Res. 2019; 39(56):460-469. https://doi.org/10.1080/10799893.2019.1683865

30. Ibrahim DA, Ismail NS. Design, synthesis and biological study of novel pyrido [2, 3-d] pyrimidine as anti-proliferative CDK2 inhibitors. Eur J Med Chem. 2011; 46(12):5825-5832. https://doi.org/10.1016/j.ejmech.2011.09.041

31. Joshi A, Bhojwani H, Joshi U. Selection of Best Crystal Structure for Initiating Docking-Based Virtual Screening Studies of CDK2 Inhibitors: A Cross-Docking and Dud Set Validation Approach. Indian Drugs. 2019; 56 (6): 77-85.

32. Joshi A, Bhojwani H, Wagal O, Begwani K, Joshi U, Sathaye S, Kanchan D (2021). Evaluation of Benzamide-chalcone Derivatives as EGFR/CDK2 inhibitor: Synthesis, in-vitro Inhibition, and Molecular Modeling Studies. Anticancer Agents Med Chem 21: 1. https://doi.org/10.2174/1871520621666210415091359

33. Fathalla OA, Ismail MA, Anwar MM, Abouzid KA, Ramadan AA. Novel 2-thiopyrimidine derivatives as CDK2 inhibitors: molecular modeling, synthesis, and anti-tumor activity evaluation. Med Chem Res. 2013; 22(2):659-673. https://doi.org/10.1007/s00044-012-0051-9

34. Ghorab MM, Ragab FA, Heiba HI, Elsayed MS, Ghorab WM. Design, synthesis and molecular modeling study of certain 4-Methylbenzenesulfonamides with CDK2 inhibitory activity as anticancer and radio-sensitizing agents. Bioorg Chem. 2018; 80:276-287. https://doi.org/10.1016/j.bioorg.2018.06.010

35. Sumirtanurdin R, Sungkar S, Hisprastin Y, Sidharta KD, Nurhikmah DD. Molecular Docking Simulation Studies of Curcumin and Its Derivatives as Cyclin-Dependent Kinase 2 Inhibitors. Turk J Pharm Sci. 2020; 17(4):417. https://doi.org/10.4274/tjps.galenos.2019.55822

36. Cherukupalli S, Chandrasekaran B, Kryštof V, Aleti RR, Sayyad N, Merugu SR, Kushwaha ND, Karpoormath R. Synthesis, anticancer evaluation, and molecular docking studies of some novel 4, 6disubstituted pyrazolo [3, 4-d] pyrimidines as cyclin-dependent kinase 2 (CDK2) inhibitors. Bioorg Chem. 2018; 79:46-59. https://doi.org/10.1016/j.bioorg.2018.02.030

37. Abd El-Sattar NE, Badawy EH, AbdEI-Hady WH, Abo-Alkasem MI, Mandour AA, Ismail NS. Design and Synthesis of New CDK2 Inhibitors Containing Thiazolone and Thiazolthione Scafold with Apoptotic Activity. Chem Pharm Bull. 2021; 69(1):106-117. https://doi.org/10.1248/cpb.c20-00714 
38. Zhang J, Zhang L, Wang Y, Zhao G. Development of anti-angiogenic tyrosine kinases inhibitors: molecular structures and binding modes. Cancer Chemother Pharmacol. 2016; 77(5):905-926. https://doi.org/10.1007/s00280-016-2961-6

39. Zhou T, Parillon L, Li F, Wang Y, Keats J, Lamore S, Xu Q, Shakespeare W, Dalgarno D, Zhu X. Crystal structure of the T315I mutant of Abl kinase. Chem Biol Drug Des. 2007; 70 (3):171-181. https://doi.org/10.1111/j.1747-0285.2007.00556.x

40. Bradshaw J, Clitherow JW. Benzanilide Derivatives. U.S. Patent 5,358,948A, October 25, 1994.

41. Biagi G, Giorgi I, Livi O, Nardi A, Calderone V, Martelli A, Martinotti E, Salerni OL. Synthesis and biological activity of novel substituted benzanilides as potassium channel activators. V. Eur J Med Chem. 2004; 39(6):491-498. https://doi.org/10.1016/j.ejmech.2004.02.006

42. Bhagat S, Sharma R, Sawant DM, Sharma L, Chakraborti AK. LiOH. H2O as a novel dual activation catalyst for highly efficient and easy synthesis of 1, 3-diaryl-2-propenones by Claisen-Schmidt condensation under mild conditions. J Mol Catal A Chem. 2006; 244(1-2):20-24.

https://doi.org/10.1016/j.molcata.2005.08.039

43. Skehan P, Storeng R, Scudiero D, Monks A, McMahon J, Vistica D, Warren JT, Bokesch H, Kenney S, Boyd MR. New colorimetric cytotoxicity assay for anticancer-drug screening. J Natl Cancer Inst. 1990; 82(13):1107-1112. https://doi.org/10.1093/jnci/82.13.1107

44. Vichai V, Kirtikara K. Sulforhodamine B colorimetric assay for cytotoxicity screening. Nat Protoc. 2006; 1(3):1112. https://doi.org/10.1038/nprot.2006.179

45. Zegzouti $\mathrm{H}$, Zdanovskaia M, Hsiao K, Goueli SA. ADP-Glo: A Bioluminescent and homogeneous ADP monitoring assay for kinases. Assay Drug Dev Technol. 2009; 7(6):560-572. https://doi.org/10.1089/adt.2009.0222

46. Friesner RA, Banks JL, Murphy RB, Halgren TA, Klicic JJ, Mainz DT, Repasky MP, Knoll EH, Shelley M, Perry JK, Shaw DE. Glide: a new approach for rapid, accurate docking and scoring. 1. Method and assessment of docking accuracy. J Med Chem. 2004; 47(7):1739-1749. https://doi.org/10.1021/jm0306430

47. Friesner RA, Murphy RB, Repasky MP, Frye LL, Greenwood JR, Halgren TA, Sanschagrin PC, Mainz DT. Extra precision glide: Docking and scoring incorporating a model of hydrophobic enclosure for protein- ligand complexes. J Med Chem. 2006; 49(21):6177-6196. https://doi.org/10.1021/jm051256o

48. Joshi AJ, Gadhwal M, Joshi UJ. Identification of potential novel EGFR inhibitors using a combination of pharmacophore and docking methods. Int J Pharm Pharm Sci. 2015; 7(6):77-91.

49. Labib MB, Philoppes JN, Lamie PF, Ahmed ER. Azole-hydrazone derivatives: Design, synthesis, in vitro biological evaluation, dual EGFR/HER2 inhibitory activity, cell cycle analysis and molecular docking study as anticancer agents. Bioorg Chem. 2018; 76:67-80. https://doi.org/10.1016/j.bioorg.2017.10.016

50. Schrödinger Release 2017-1: Protein Preparation Wizard; Epik, Schrödinger, LLC, New York, NY, 2017; Impact, Schrödinger, LLC, New York, NY, 2017. 
51. Schrodinger Release 2017-1: Glide, Schrödinger, LLC, New York, NY, 2017.

52. Schrödinger Release 2017-1: LigPrep, Schrödinger, LLC, New York, NY, 2017.

53. Schrodinger Release 2016-4: Desmond Molecular Dynamics System, D. E. Shaw Research, New York, NY, 2016.

54. Bowers KJ, Chow DE, Xu H, Dror RO, Eastwood MP, Gregersen BA, Klepeis JL, Kolossvary I, Moraes MA, Sacerdoti FD, Salmon JK. Scalable algorithms for molecular dynamics simulations on commodity clusters. InSC'06: Proceedings of the 2006 ACM/IEEE Conference on Supercomputing 43.

55. Karthiga A, Tripathi SK, Shanmugam R, Suryanarayanan V, Singh SK. Targeting the cyclin-binding groove site to inhibit the catalytic activity of CDK2/cyclin A complex using p27 KIP1-derived peptidomimetic inhibitors. J Chem Biol. 2015; 8(1):11-24. https://doi.org/10.1007/s12154-014-0124$y$

56. Jorgensen WL, Chandrasekhar J, Madura JD, Impey RW, Klein ML. Comparison of simple potential functions for simulating liquid water. Int J Chem Phys. 1983; 79(2):926-35.

57. Lambrakos SG, Boris JP, Oran ES, Chandrasekhar I, Nagumo M. A modified shake algorithm for maintaining rigid bonds in molecular dynamics simulations of large molecules. J Chem Phys. 1989; 85(2):473-486.

58. Tuckerman MB, Berne BJ, Martyna GJ. Reversible multiple time scale molecular dynamics. J Chem Phys. 1992; 97(3):1990-2001.

59. Martyna GJ, Tobias DJ, Klein ML. Constant pressure molecular dynamics algorithms. J Chem Phys. 1994; 01(5):4177-4189.

\section{Figures}


<smiles>O=c1c(-c2ccc(O)cc2)coc2cc(O)cc(O)c12</smiles><smiles>[R][X]c1ccccc1C1CC(c2c(O)c3ccccc3oc2=O)=NN1[R]</smiles>

Coumarin derivatives<smiles>O=c1c(O)c(-c2ccc(O)cc2)oc2cc(O)cc(O)c12</smiles><smiles>CN1CC[C@H](c2c(O)cc(O)c3c(=O)cc(-c4ccccc4Cl)oc23)[C@H](O)C1</smiles>

Flavopiridol<smiles>O=c1cc(-c2ccc(O)cc2)oc2cc(O)cc(O)c12</smiles>

Apigenin<smiles>O=c1ccc2ccccc2o1</smiles>

Coumarin<smiles>O=C(/C=C/c1ccc(O)cc1)c1ccc(O)cc1O</smiles>

Isoliquiritigenin<smiles>C=CC(C)(C)c1cc(/C=C/C(=O)c2ccc(O)cc2)c(OC)cc1O</smiles>

Licochalcone A

\section{Curcumin}<smiles>COc1cc(/C=C/C(=O)CC(=O)/C=C/c2ccc(O)c(OC)c2)ccc1O</smiles><smiles>COc1cc(/C=C/C(=O)O)ccc1O</smiles>

Ferulic acid<smiles>O=C(O)/C=C/c1ccc(O)c(O)c1</smiles>

Caffeic acid<smiles>O=C(O)/C=C/c1ccccc1</smiles>

Cinnamic acid

\section{Figure 1}

Compounds reported in the literature with potential activity on CDK2 
<smiles>O=C(O)/C=C/c1ccccc1</smiles><smiles>[R]c1ccc(-c2cc(=O)c3ccccc3o2)cc1</smiles>

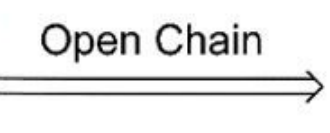<smiles>[R]c1ccc(C=CC(=O)c2ccccc2)cc1</smiles>
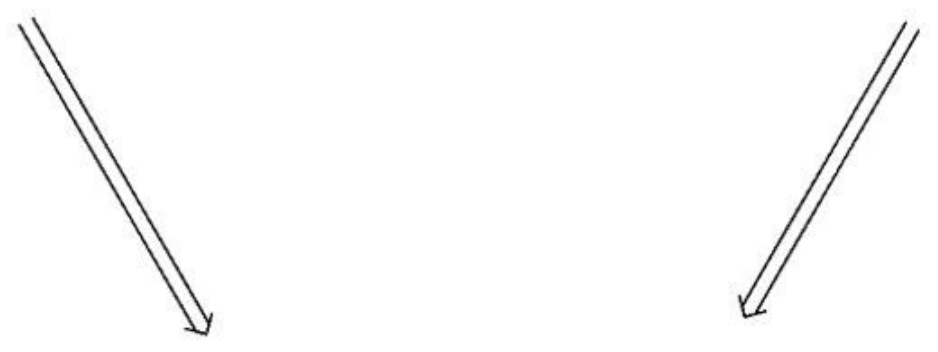<smiles>[R][X]c1cccc(/C=C/C(=O)c2cccc(NC(=O)/C=C/c3ccccc3)c2)c1</smiles>

Cinnamoyl Chalcones (2a-2m)

Figure 2

Design Strategy for the Cinnamamide-chalcone Derivatives 

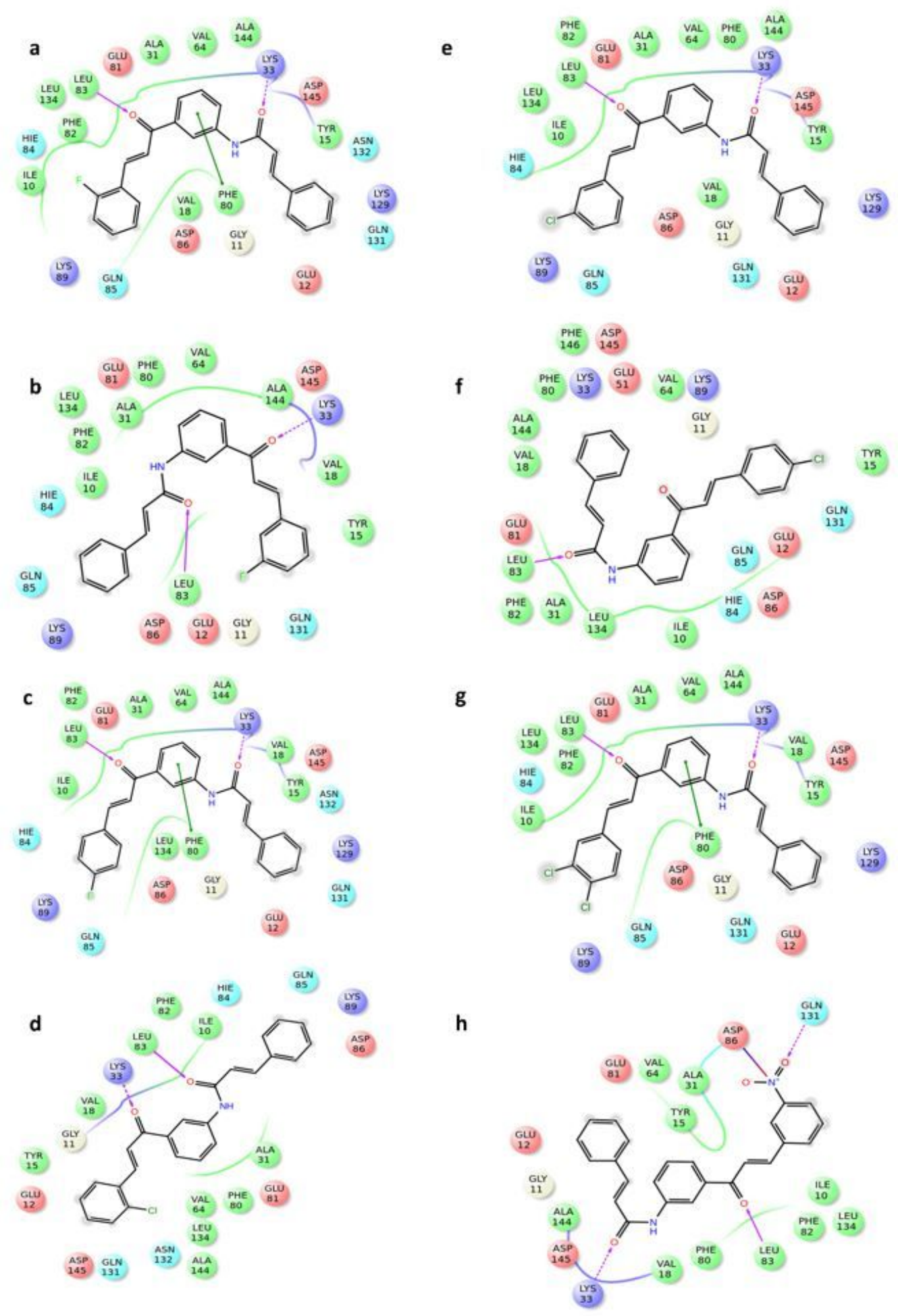

\section{Figure 3}

2D ligand interaction diagram for the docking of synthesized compounds in CDK2 active sites where (a) compound 2e, (b) compound 2f, (c) compound 2g, (d) compound 2h, (e) compound 2i, (f) compound 2j, (g) compound $2 \mathrm{k}$, and $(\mathrm{h})$ compound $2 \mathrm{l}$. Solid pink arrow indicates backbone hydrogen bond, dashed pink arrow indicates side-chain hydrogen bond, and green line indicates pi-pi stacking. Red-blue line indicates salt-bridge. 

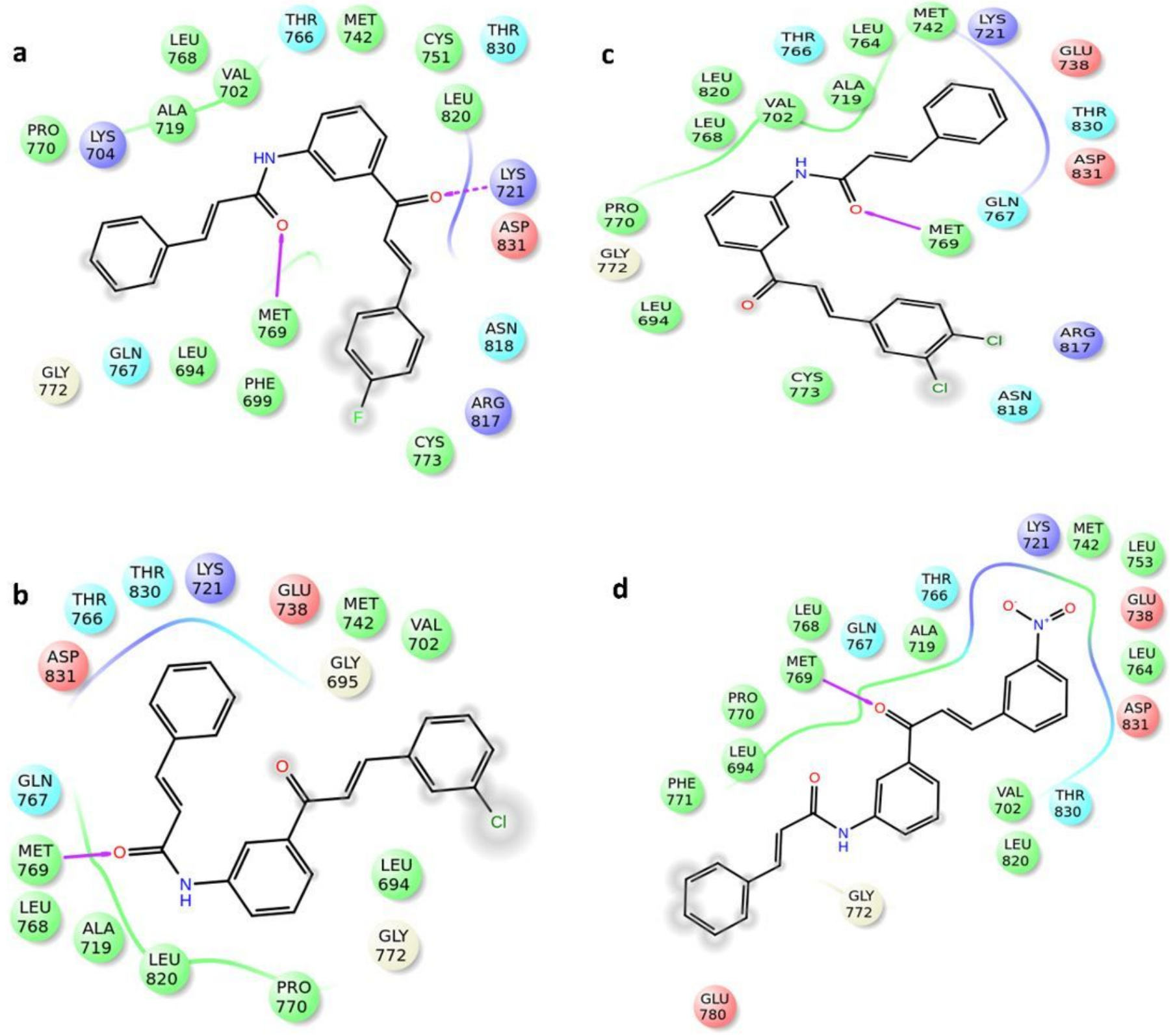

\section{Figure 4}

2D ligand interaction diagram for the docking of synthesized compounds in EGFR active sites where (a) compound 2g, (b) compound 2i, (c) compound 2k, and (d) compound 2l. Solid pink arrow indicates backbone hydrogen bond and dashed pink arrow indicates side-chain hydrogen bond. 
a

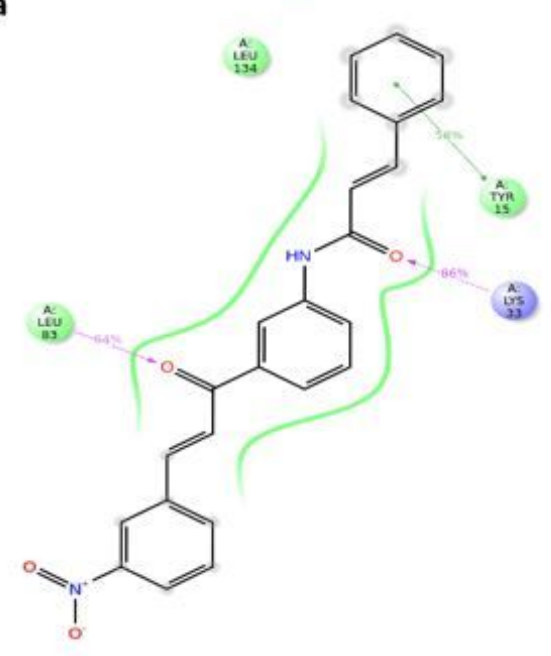

b

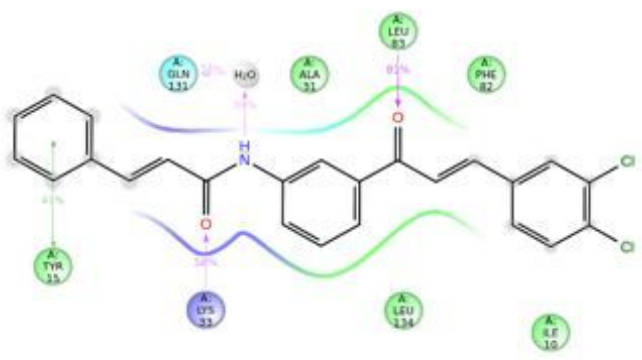

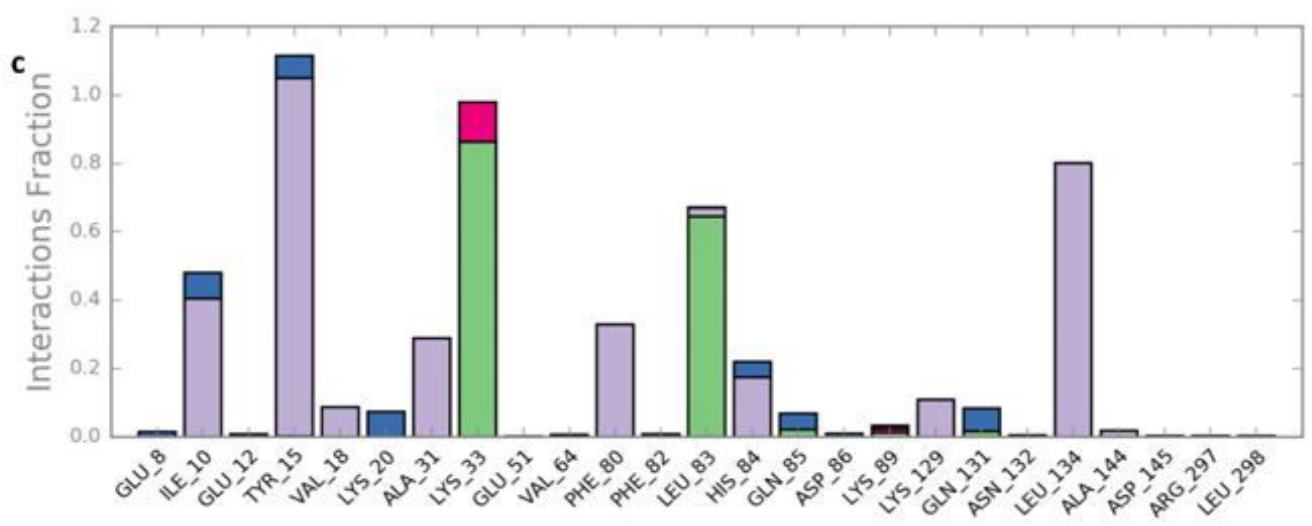

$\square$ H-bonds $\square$ Hydrophobic $\square$ lonic $\square$ Water bridges

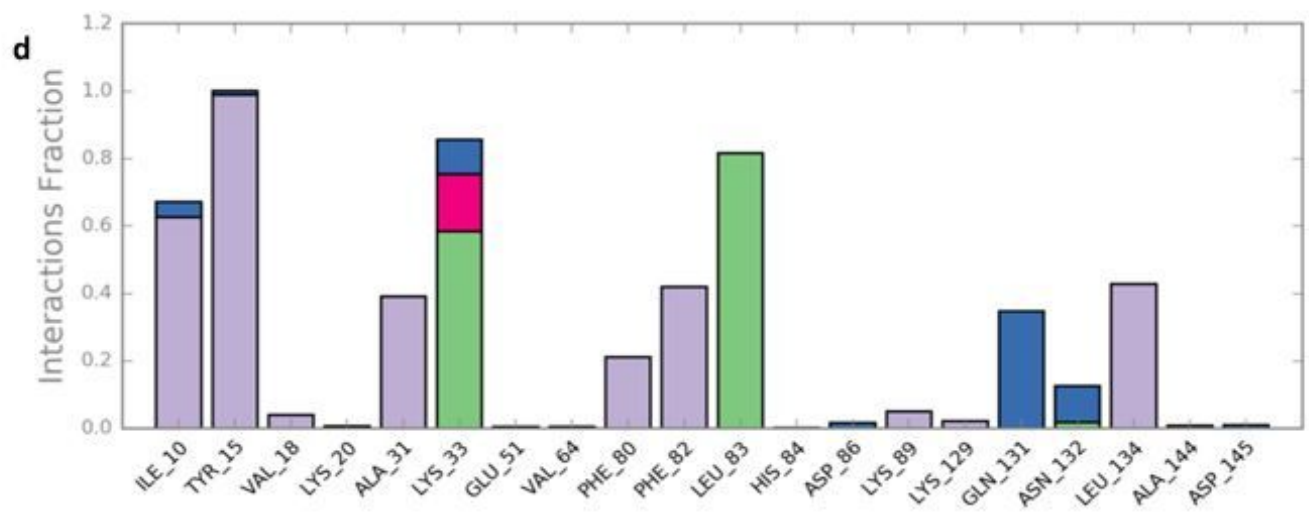

$\square$ H-bonds $\square$ Hydrophobic $\square$ lonic $\square$ Water bridges

\section{Figure 5}

2D ligand interaction diagram and histogram plot for the fraction of interactions with the amino acid residues in the CDK2 active site for the synthesized compounds. (a) 2D ligand interaction for compound 2I, (b) 2D ligand interaction for compound 2k, (c) histogram plot for compound 2l, and (d) histogram plot for compound $2 k$. 


\section{Supplementary Files}

This is a list of supplementary files associated with this preprint. Click to download.

- scheme1.jpg

- SupplementaryMaterialFigureandTablecompressed.pdf

- SupplementaryMaterialSpectralData15052021.pdf 